A RCHIWA, BIBLIOTEKI

I MUZEA KOŚCIELNE 110 (2018)

https://doi.org/10.31743/abmk.2018.110.12

KS. ŁUKASZ KRUCKI* - GNIEZNO

JUSTYNA MIZERKA** - GNIEZNO

\title{
ZESPÓŁ ARCHIWUM PRYMASA POLSKI W ZASOBIE ARCHIWUM ARCHIDIECEZJALNEGO W GNIEŹNIE
}

Archiwum Archidiecezjalne w Gnieźnie, chociaż zostało powołane do istnienia dopiero w 1960 r. ${ }^{1}$, w swoim zasobie skupia archiwalia o znacznie starszej metryce, sięgającej nierzadko czasów średniowiecza. Wytworzone na przestrzeni wieków przez różne instytucje kościelne akta odzwierciedlają pozycję archidiecezji (i metropolii) gnieźnieńskiej w strukturze Kościoła polskiego oraz wskazują na znaczenie arcybiskupów gnieźnieńskich (od XV w. prymasów Polski) wśród polskiego episkopatu. Zasób Archiwum Archidiecezjalnego w Gnieźnie jest przez to istotnym elementem dziedzictwa narodowego, który obejmuje obecnie 1.283 zespoły. Głównie są to: akta konsystorza generalnego, akta kurii metropolitalnej, akta trybunału metropolitalnego, akta kapituły metropolitalnej, zbiory dokumentów, zbiór listów, akta seminarium duchownego, akta dekanalne oraz akta parafialne ${ }^{2}$. Jednym z najcenniejszych jest zespół noszący nazwę: Archiwum Prymasa Polski. Odnosi się on do działalności prymasów Polski - kard. Edmunda Dalbora i kard. Augusta Hlonda ${ }^{3}$, a przez to ukazuje ich wielopłaszczyznowe

* Ks. Łukasz Krucki - dr historii Kościoła; zastępca dyrektora Archiwum Archidiecezjalnego w Gnieźnie, wykładowca w Prymasowskim Wyższym Seminarium Duchownym w Gnieźnie; e-mail: krucki@op.pl

ORCID 0000-0003-2972-9113

** Justyna Mizerka - mgr archeologii; kustosz w Archiwum Archidiecezjalnym w Gnieźnie; e-mail: jmizerka@gniezno.opoka.org.pl

ORCID 0000-0002-3454-671X

${ }^{1}$ Archiwum Archidiecezjalne w Gnieźnie (dalej: AAG), Akta Kurii Metropolitalnej. Dział I (dalej: AKM I), sygn. 1823, Statut Archiwum Archidiecezjalnego w Gnieźnie; „Wiadomości Archidiecezji Gnieźnieńskiej”, 43 (1988) nr 7-8-9, s. 183-185.

${ }^{2}$ M. Aleksandrowicz, J. Rył, W. Zientarski, Archiwum Archidiecezjalne w Gnieźnie, w: Dzieje Poznania i województwa poznańskiego (w granicach z 1974 r.). Informator o materiałach archiwalnych, red. Cz. Skopowski, Warszawa 1982, s. 85.

${ }^{3}$ Archiwum prymasowskie odnoszące się do działalności prymasów Polski doby staropolskiej, obejmujące 163 tomy akt, w okresie zaborów zostało na polecenie abpa Zygmunta Felińskiego prze- 
zaangażowanie na niwie kościelnej, państwowej oraz międzynarodowej w latach 1919-1948. W jubileuszowym roku 600-lecia zaistnienia prymasostwa w Polsce należy przybliżyć szerszemu gronu odbiorców rangę tych akt oraz przekazać ich inwentarz. Powinno się to okazać przydatne zwłaszcza dla badaczy zgłębiających różne dziedziny historii (nie tylko historię Kościoła) w okresie dwudziestolecia międzywojennego, II wojny światowej oraz tworzenia się nowej rzeczywistości polityczno-kościelnej po $1945 \mathrm{r}$.

\section{Kancelaria Prymasa Polski}

W okresie niewoli narodowej zaborcy zakazali arcybiskupom gnieźnieńskim (od 1821 r. gnieźnieńskim i poznańskim) używania tytułu prymasa Polski, a jednocześnie przyczynili się do ukrócenia ich rozległej władzy jurysdykcyjnej, uzyskiwanej sukcesywnie na przestrzeni wieków. Sytuacja zmieniła się w 1918 r., gdy Polska odzyskała niepodległość, a z początkiem roku następnego Wielkopolska znalazła się w granicach odrodzonego państwa polskiego. Wydawać się wówczas mogło, że odtąd kard. Edmund Dalbor (jako arcybiskup gnieźnieński i poznański) bezsprzecznie stanie się liderem polskiego episkopatu i zajmie w nim pozycję, która przysługiwała prymasom Polski przed rozbiorami. Wytworzone $\mathrm{w}$ trakcie ponad stuletniego okresu niewoli narodowej zmiany sprawiły jednak, że jego pozycja została zachwiana przez drugiego polskiego kardynała - Aleksandra Kakowskiego, arcybiskupa warszawskiego, tytułującego się prymasem Królestwa Polskiego. Wzmagający się i długo nierozstrzygnięty (do 1925 r.) spór między tymi dwoma hierarchami podzielił zarówno poszczególnych biskupów, jak i polskie społeczeństwo. Wpłynął również w pewnym sensie na fakt ograniczenia ogólnopolskiej aktywności arcybiskupa gnieźnieńskiego i poznańskiego, prymasa Polski. Niemałym utrudnieniem było również i to, że w trakcie ponad stuletniego okresu rozbiorów likwidacji uległy wszelkie agendy związane z organizacją i funkcjonowaniem kancelarii prymasowskiej doby staropolskiej, która mieściła się w Łowiczu. Nic zatem dziwnego, że w pierwszych latach po odzyskaniu przez Polskę niepodległości, gdy system kancelarii prymasowskiej jeszcze się nie wykrystalizował, kard. Edmund Dalbor musiał prowadzić swoją działalność aktotwórczą w oparciu o istniejące w archidiecezjach gnieźnieńskiej i poznańskiej kościelne instytucje centralne. Te natomiast posiadały skomplikowaną strukturę, wygenerowaną przez okoliczności związane z obostrzeniami nałożonymi przez zaborcę pruskiego. Przede wszystkim wpłynął na nią fakt połączenia w $1821 \mathrm{r}$. archidiecezji gnieźnieńskiej i poznańskiej unią personalną. Wprawdzie tenor bulli De salute animarum stanowił jedynie o osobie wspólnego arcybiskupa dla obu wielkopolskich archidiecezji, przy zachowaniu odrębności pozostałych urzędów diecezjalnych, w praktyce jednak scentralizowano poszczególne instytucje w celu lepszego nad nimi nadzoru. W ten sposób ustanowiono na wzór niemiecki instytucję Ordynariatu Arcybiskupiego w Poznaniu, który miał

wiezione z Łowicza do Warszawy. W stolicy uległo spaleniu podczas Powstania Warszawskiego. Zob. H. Rybus, Regesty wybranych zapisek z akt działalności arcybiskupów gnieźnieńskich, „Archiwa, Biblioteki i Muzea Kościelne" (dalej: ABMK), 3 (1961) s. 113-115. 
pełnić rolę przybocznego biura arcybiskupa. Przez ordynariat miały przechodzić wszelkie sprawy wymagające decyzji ordynariusza, co sprawiło, że stał się on rodzajem ,super kurii”, której podlegały konsystorze generalne w Gnieźnie i Poznaniu (Zob. Schemat nr 1) . $^{\text {Po }} 1918$ r. Ordynariat Arcybiskupi w Poznaniu uzyskał dodatkowe kompetencje. Stał się instytucją załatwiającą sprawy związane z działalnością wielkopolskiego hierarchy jako prymasa Polski.

Schemat nr 1. Struktura organizacyjno-administracyjna archidiecezji gnieźnieńskiej i poznańskiej do 31 I 1927 r.

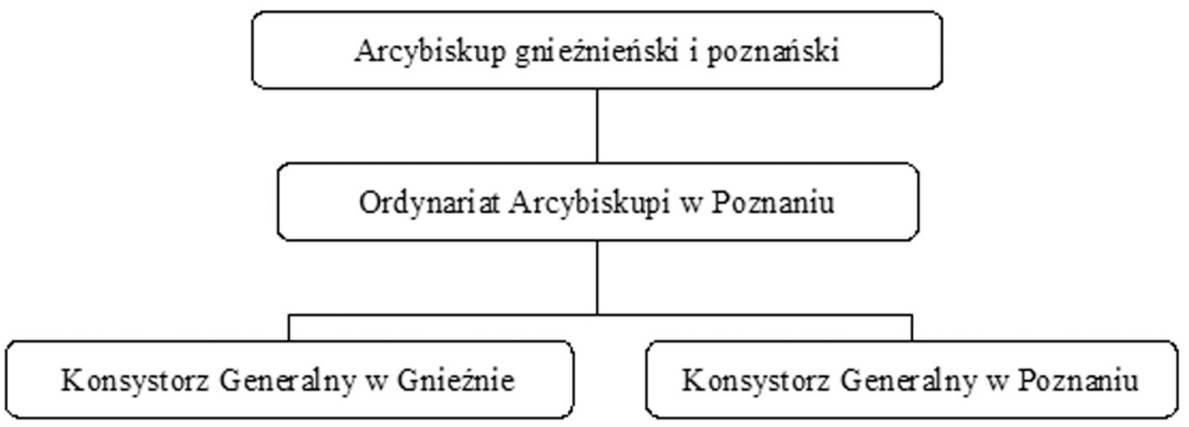

W 1919 r. zaprowadzono system prowadzenia akt prymasowskich w oparciu o trzy działy:

- Dział I: Prymas Polski;

- Dział II: Ordynariusz gnieźnieński i poznański;

- Dział III: Opiekun (od 1931 r. Protektor) Spraw Wychodźstwa.

Przyrost obowiązków niewątpliwie stanowił kłopot dla niewielkiego zespołu pracowników ordynariatu, ale w okresie rządów kard. Edmunda Dalbora nie poczyniono $\mathrm{w}$ tej dziedzinie żadnych reform. Te nastąpiły dopiero z nastaniem nowego arcybiskupa gnieźnieńskiego i poznańskiego - Augusta Hlonda (Zob. Tabela $\mathrm{nr}$ 1).

Tabela 1. Obsada Ordynariatu Arcybiskupiego w Poznaniu.

\begin{tabular}{|l|l|l|}
\hline \multicolumn{1}{|c|}{ Funkcja } & \multicolumn{1}{|c|}{ Urzędujący w 1919 r. } & \multicolumn{1}{c|}{ Urzędujący w 1926 r. } \\
\hline \multicolumn{1}{|c|}{$\mathbf{2}$} & \multicolumn{1}{c|}{$\mathbf{2}$} & \multicolumn{1}{c|}{$\mathbf{3}$} \\
\hline Arcybiskup & kard. Edmund Dalbor & kard. August Hlond \\
\hline Kapelan & ks. Tadeusz Zakrzewski & ks. Nikodem Mędlewski \\
\hline
\end{tabular}

${ }^{4}$ S. Wilk, Archidiecezja gnieźnieńska w II Rzeczypospolitej. Administracja archidiecezji pod rządami kard. Edmunda Dalbora i kard. Augusta Hlonda, Lublin 1987, s. 30-37; tenże, Archidiecezja gnieźnieńska pod rządami arcybiskupów: Edmunda Dalbora (1915-1926) i Augusta Hlonda (1926-1948), w: 1000 lat Archidiecezji Gnieźnieńskiej, red. J. Strzelczyk, J. Górny, Gniezno 2000, s. 384-387. 


\begin{tabular}{|c|c|c|}
\hline 1 & 2 & 3 \\
\hline \multirow{3}{*}{ Radcy w ordynariacie } & \multirow{3}{*}{-} & bp Stanisław Łukomski \\
\hline & & ks. Henryk Zborowski \\
\hline & & vacat \\
\hline Asesor & - & ks. Stanisław Czapski \\
\hline Dyrektor kancelarii & ks. Stanisław Czapski & ks. Franciszek Lewandowski \\
\hline \multirow{3}{*}{ Sekretarze kancelarii } & \multirow{3}{*}{ ks. Leonard Kurpisz } & ks. Nikodem Mędlewski \\
\hline & & ks. Czesław Wojciechowski \\
\hline & & ks. Kornel Witaszek \\
\hline Prezes Rady Ordynariatu & kard. Edmund Dalbor & kard. August Hlond \\
\hline Wiceprezes Rady Ordynariatu & $\begin{array}{l}\text { Vacat po śmierci bpa Pawła } \\
\text { Jandzika }\end{array}$ & bp Stanisław Łukomski \\
\hline \multirow{5}{*}{ Radcy Rady Ordynariatu } & ks. Władysław Meszczyński & bp Antoni Laubitz \\
\hline & ks. Robert Weimann & ks. Czesław Meissner \\
\hline & ks. Czesław Meissner & ks. Stanisław Adamski \\
\hline & \multirow{2}{*}{ ks. Stanisław Łukomski } & ks. Franciszek Ruciński \\
\hline & & ks. Henryk Zborowski \\
\hline
\end{tabular}

Źródło: Elenchus archidiecezji gnieźnieńskiej 1919; Elenchus archidiecezji gnieźnieńskiej 1926.

Niemniej, odnosząc się jeszcze do kwestii związanej z kancelaryjną działalnością kard. Edmunda Dalbora, należy pamiętać, że w 1922 r. przy Biurze Episkopatu w Warszawie została ustanowiona „Kancelaria Prymasowska”. Fakt ten nie miał jednak - według Stanisława Wilka SDB - podłoża jurysdykcyjnego wobec innych biskupów ${ }^{5}$. Nie służył również sprawom ściśle kancelaryjnym. Był on jedynie formą wyrażenia pretensji do pałacu prymasowskiego w stolicy, który kard.

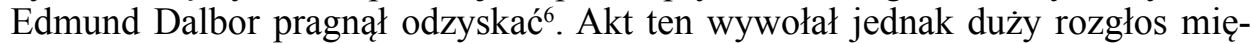
dzy hierarchami, którzy upatrywali w nim chęć wskrzeszenia przedrozbiorowych prerogatyw prymasów Polski. Takiego zamiaru dopatrzył się również badacz prymasostwa Edmunda Dalbora - ks. Marian Fąka, gdy zauważył, że w sprawę ustanowienia „Kancelarii Prymasowskiej” włączył się nawet nuncjusz Lorenzo Lauri i „ostro zwalczał pretensje arcybiskupa gnieźnieńskiego do wykonywania jurysdykcji prymasowskiej i zabiegał w Rzymie o zamknięcie kancelarii prymasowskiej" . Doszło nawet do tego, że prymas Edmund Dalbor musiał złożyć wyjaśnienie z celowości swojego postanowienia na posiedzeniu Komitetu Biskupów. Zostało ono uznane przez biskupów za wystarczające i cała sprawa teoretycznie poszła w niepamięć. Dojmujące dla prymasa doświadczenie sprawiło jednak, że zaniechał on planów głębszej reformy kancelarii konsystorskiej, by w ten sposób

${ }^{5}$ S. Wilk, Funkcja Prymasa Polski w II Rzeczypospolitej, „Studia Theologica Varsaviensia”, 26 (1988) nr 2, s. 178.

${ }^{6}$ Zob. AAG, Archiwum Prymasa Polski. Dział I, sygn. 169.

${ }^{7}$ M. Fąka, Kwestia prymasostwa w okresie arcybiskupich rządów kardynata Edmunda Dalbora (1915-1926), „Prawo Kanoniczne”, 20 (1977) nr 3-4, s. 120-121. 
nie zadrażniać i tak już napiętych relacji z biskupami i nuncjuszem apostolskim w Polsce ${ }^{8}$.

Niezbędnej reformy systemu kancelaryjnego podjął się następca Edmunda Dalbora - August Hlond. Z końcem stycznia 1927 r. rozwiązał on Ordynariat Arcybiskupi w Poznaniu, a podlegające mu konsystorze generalne w Gnieźnie i Poznaniu przekształcił w kurie diecezjalne i sądy biskupie. Dodatkowo na mocy tego samego dekretu - z 31 I 1927 r. - ustanowił Kancelarię Prymasa Polski (Zob. Schemat nr 2) ${ }^{9}$.

Schemat 2. Struktura organizacyjno-administracyjna archidiecezji gnieźnieńskiej i poznańskiej po 31 I 1927 r.

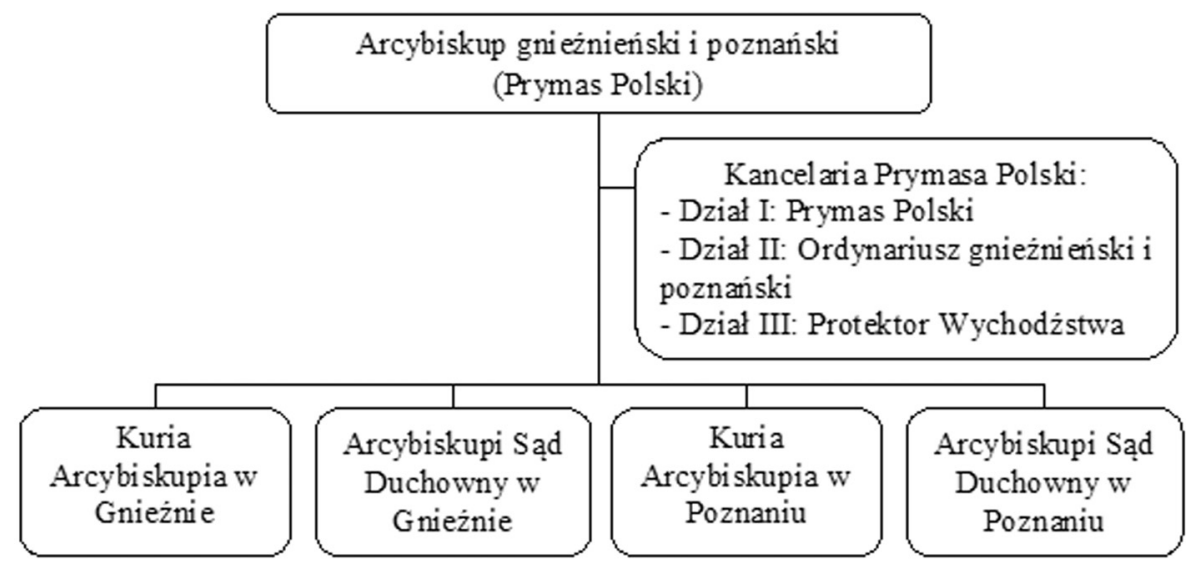

Z założenia Kancelaria Prymasa Polski miała obejmować trzy działy:

1) sprawy związane z prymasostwem (tzw. generalia),

2) kwestie odnoszące się do prymasa jako arcybiskupa gnieźnieńskiego i poznańskiego (tzw. ordynariat);

3) sprawy protektoratu nad Polonią.

W rzeczywistości jej uprawnienia były znacznie szersze. Przydzielono jej sprawy Seminarium Arcybiskupiego w Poznaniu (wraz z nadzorem nad jego uposażeniem), a także kwestie związane $\mathrm{z}$ wewnętrznym majątkiem obu wielkopolskich archidiecezji ${ }^{10}$. Ponadto Kancelaria Prymasa Polski miała zając się sprawami związanymi z działalnością Sekretariatów Generalnych, Misji Zagranicznych, opieki duszpasterskiej nad Polonią, studiów zagranicznych du-

${ }^{8}$ Wilk, Funkcja Prymasa, s. 178.

${ }^{9}$ Ł. Krucki, Jak powstała Kuria Arcybiskupia w Gnieźnie? O ustanowieniu centralnego urzę$d u$ archidiecezji gnieźnieńskiej $w$ dwudziestoleciu międzywojennym, w: Kurie (archi)diecezjalne Kościoła rzymskokatolickiego w II Rzeczypospolitej, red. M. Dębowska, Lublin 2016, s. 24.

${ }^{10}$ Wilk, Archidiecezja gnieźnieńska, s. 29. 
chowieństwa, Unii Apostolskiej oraz Arcybractwa Wiecznej Adoracji ${ }^{11}$. Nie można również zapominać, że Kancelarii Prymasa Polski zlecono wydawanie urzędowego pisma - „Miesięcznika Kościelnego Archidiecezji Gnieźnieńskiej i Poznańskiej”'12 oraz corocznych elenchusów, które od 1929 r. określane były jako Rocznik archidiecezji gnieźnieńskiej i poznańskiej ${ }^{13}$. Z przytoczonego zakresu kompetencji jasno wynika, że Kancelaria Prymasa Polski przejęła część spraw znajdujących się uprzednio w sferze zainteresowań Ordynariatu Arcybiskupiego. Istotną różnicą było natomiast to, że nie stanowiła ona instytucji nadrzędnej ani w stosunku do kurii arcybiskupich (w Gnieźnie i Poznaniu), ani tym bardziej w stosunku do sądów kościelnych ulokowanych w wielkopolskich stolicach arcybiskupich $^{14}$.

W Kancelarii Prymasa Polski starano się zatrudniać osoby kompetentne, stąd też w początkowym okresie w jej skład wchodzili duchowni pracujący uprzednio w Ordynariacie Arcybiskupim w Poznaniu. Z czasem, ze względów oczywistych, następowała fluktuacja na poszczególnych urzędach, co było efektem awansu niektórych pracowników, bądź też wyrazem naturalnej wymiany pokoleniowej (Zob. Tabela nr 2).

Tabela 2. Obsada Kancelarii Prymasa Polski

\begin{tabular}{|c|c|c|}
\hline Funkcja & Urzędujący w 1928 r. & Urzędujący w 1938 r. \\
\hline Dyrektor & ks. Franciszek Lewandowski & ks. Henryk Zborowski \\
\hline \multirow{3}{*}{ Referenci } & ks. Henryk Zborowski & ks. Stefan Durzyński \\
\hline & ks. Stanisław Czapski & \multirow{2}{*}{ ks. Franciszek Lewandowski } \\
\hline & ks. Jan Noryśkiewicz & \\
\hline \multirow{3}{*}{ Sekretarze } & ks. Franciszek Rutkowski & \multirow{3}{*}{-} \\
\hline & ks. Stefan Abt & \\
\hline & ks. Józef Pawlak & \\
\hline Kierownik biura & - & ks. Władysław Staniszewski \\
\hline
\end{tabular}

Źródło: Elenchus archidiecezji gnieźnieńskiej 1928; Rocznik archidiecezji gnieźnieńskiej i poznańskiej 1938.

${ }^{11}$ Co do właściwego adresowania, „Miesięcznik Kościelny Archidiecezji Gnieźnieńskiej i Poznańskiej”, 44 (1927) nr 2, s. 1; S. Kosiński, August Hlond 1926-1948, w: Na stolicy prymasowskiej w Gnieźnie i Poznaniu. Szkice o prymasach Polski w okresie niewoli narodowej $i$ w II Rzeczypospolitej, red. F. Lenort, Poznań 1982, s. 338.

${ }^{12}$ Do 1934 r. tytuł pisma urzędowego brzmiał: „Miesięcznik Kościelny dla Archidiecezji Gnieźnieńskiej i Poznańskiej”. Zob. L. Wilczyński, Ordynariat Arcybiskupi w Poznaniu i Kancelaria Prymasa Polski w dwudziestoleciu międzywojennym, „Ecclesia. Studia z dziejów Wielkopolski”, 1 (2003) s. 273.

${ }^{13}$ Ł. Krucki, Rubrycele i schematyzmy archidiecezji gnieźnieńskiej. Katalog druków przechowywanych w Archiwum Archidiecezjalnym w Gnieźnie, Gniezno 2016, s. 43.

${ }^{14}$ Wilczyński, Ordynariat Arcybiskupi, s. 268-270. 
Na czele Kancelarii Prymasa Polski stał dyrektor, którego od 1930 r. określano jako szefa kancelarii. Jemu podlegali referenci i sekretarze. Początkowo personel kancelarii był dość liczny, składał się z 7 osób. Z czasem jednak, z przyczyn ekonomicznych, został ograniczony, tak iż w 1938 r. obejmował jedynie szefa kancelarii, dwóch referentów i kierownika biura (Zob. Tabela nr 2). Mimo skromnej obsady osobowej wypełniał polecenia prymasa Polski ${ }^{15}$.

Metoda pracy Kancelarii Prymasa Polski okresu międzywojennego była tożsama z przyjętym powszechnie systemem akt sprawy, który w zunifikowanych archidiecezjach wielkopolskich obowiązywał od XIX w. ${ }^{16}$

\section{Charakterystyka zespołu}

Archiwum Prymasa Polski stanowią 493 jednostki archiwalne ${ }^{17}$, zgrupowane w trzech działach:

Dział I - Prymas Polski - obejmuje sprawy związane z szeroko pojmowaną aktywnością kardynałów Edmunda Dalbora i Augusta Hlonda na polu kościelnym i państwowym (228 jednostek).

Dział II - Ordynariusz gnieźnieński i poznański - skupia sprawy odnoszące się do działalności arcybiskupów Edmunda Dalbora i Augusta Hlonda jako ordynariuszy wielkopolskich archidiecezji (105 jednostek).

Dział III - Protektor Spraw Wychodźstwa - podejmuje m.in. kwestie związane $\mathrm{z}$ aktywnością prymasów okresu międzywojennego wśród Polonii i na jej rzecz (120 jednostek).

Dodatkowo - post factum - został wyodrębniony dział IV (40 jednostek), który stanowi efekt kancelaryjnej działalności prymasa Augusta Hlonda z czasu II wojny światowej. Zaznaczyć jednak należy, iż dział ten jest jednak niekompletny, gdyż zasadnicza część wojennej korespondencji kard. Augusta Hlonda, przechowywana początkowo w Lądzie i opracowana przez ks. Stanisława Kosińskiego SDB, znajduje się obecnie w Archiwum Salezjańskim Inspektorii Pilskiej.

W zespole Archiwum Prymasa Polski znajdują się również akta z lat 19451948, ale te są dopiero w trakcie opracowywania. Do 30 czerwca 2017 r. uporządkowano i opracowano 65 teczek stanowiących jego zasób.

\section{Wojenne i powojenne losy Archiwum Prymasa Polski}

Akta Kancelarii Prymasa Polski do 1939 r. znajdowały się w Poznaniu. Zaraz po wybuchu wojny prymas August Hlond podjął decyzję, żeby najważniejsze jednostki zabrać ze sobą i w ten sposób rozpoczęła się ich wojenna migracja. Przewieziono je do Lubartowa, gdzie 8 września zostały zdeponowane w klasztorze Kapucynów. Nie uchroniło to akt przed poważnymi stratami wynikającymi

${ }^{15}$ M. Banaszak, F. Lenort, Archiwum Archidiecezjalne w Poznaniu, w: Dzieje Poznania $i$ województwa poznańskiego ( $w$ granicach z 1974 r.). Informator o materiałach archiwalnych, red. Cz. Skopowski, Warszawa 1982, s. 371.

${ }^{16} \mathrm{~S}$. Wilk, Kancelaria konsystorska $w$ zaborze pruskim na przełomie XIX $i$ XX w., ABMK, 64 (1995) s. 41-47.

${ }^{17}$ Stan na 30 czerwca $2017 \mathrm{r}$. 
z niewłaściwego przechowywania ${ }^{18}$. Akta pozostawione w Poznaniu uległy natomiast rozproszeniu i częściowej destrukcji. Niemcy, którzy wkroczyli do Poznania, przejęli wszystkie dokumenty, a następnie dokonali ich selekcji. Te, które uznali za bezwartościowe przekazali na utylizację do papierni w Czerwonaku pod Poznaniem. Pozostałe akta zostały złączone z archiwaliami wytworzonymi przez kancelarię arcybiskupów gnieźnieńskich i poznańskich doby zaborów (przed wojną w Archiwum Archidiecezjalnym w Poznaniu było ok. 3.300 jednostek tych akt). Jako że w latach 1939-1945 były one przechowywane w różnych miejscach i w rozmaitych warunkach, stąd też niekorzystnie wpłynęło to na ich układ oraz stan zachowania ${ }^{19}$.

Po wojnie, w 1946 r., rozwiązano unię personalną łączącą Gniezno i Poznań, a $\mathrm{w}$ jej miejsce ustanowiono inną, łączącą archidiecezję gnieźnieńską $\mathrm{z}$ archidiecezją warszawską. W zaistniałej sytuacji kard. August Hlond przeniósł się z Poznania do Warszawy i tam też zabrał swoje archiwum. Lata 1946-1948 okazały się jednak bardzo burzliwe, stąd też - według relacji przełożonego generalnego Towarzystwa Chrystusowego w latach 1976-1983, ks. Czesława Kamieńskiego, a zasłyszanej od bpa Antoniego Baraniaka ${ }^{20}$ - jeszcze za życia kard. Hlonda (†22 X 1948 r.) zdecydowano by w katedrze gnieźnieńskiej ukryć część Archiwum Prymasa Polski pochodzącą z czasu wojny i w ten sposób uchronić ją przed przejęciem przez władze komunistyczne. Odmienną wersję faktu ukrycia w katedrze gnieźnieńskiej Archiwum Prymasa Polski z lat 1939-1945 przekazał ks. Władysław Ziętarski (dyrektor Archiwum Archidiecezjalnego w Gnieźnie w latach 1960-1991). Twierdził on, że archiwum prymasowskie czasu wojny zostało schowane przez bpa Antoniego Baraniaka i ks. kan. Stefana Durzyńskiego tuż przed aresztowaniem prymasa Stefana Wyszyńskiego, we wrześniu 1953 r. Po 1956 r. zarówno bp Antoni Baraniak, jak i kan. Stefan Durzyński poszukiwali tych akt, ale nie mogli ich odnaleźć. Udało się to dopiero jesienią 1964 r. ks. Władysławowi Ziętarskiemu, który przy rozbieraniu regałów podczas przebudowy pomieszczeń bibliotecznych w archiwum, natrafił na 38 dobrze zachowanych teczek schowanych w narożniku za regałem bibliotecznym ${ }^{21}$. O całej sprawie niezwłocznie powiadomił prymasa Stefana Wyszyńskiego, który w Gnieźnie, jako stolicy prymasowskiej, upatrywał odtąd miejsca przechowywania także i dla innych akt wytworzonych przez kancelarię prymasowską okresu międzywojennego.

\section{Opracowanie zespołu}

Archiwum Prymasa Polski zawierające archiwalia z okresu międzywojennego zostało przekazanie do Archiwum Archidiecezjalnego w Gnieźnie w 1969 r..$^{22}$ Wpływ na to miała niewątpliwie osobista decyzja prymasa Stefana Wyszyńskie-

${ }^{18}$ B. Filipiak, Niektóre wiadomości o Kardynale Prymasie Auguście Hlondzie z czasów wojny 1939-1945, „Sacrum Poloniae Millennium”, 11 (1965) s. 480.

${ }^{19}$ Banaszak, Lenort, Archiwum Archidiecezjalne, s. 371.

${ }^{20}$ AAG, Sekretariat Archiwum Archidiecezjalnego w Gnieźnie, Notatki ks. Mariana Aleksandrowicza do katalogu Archiwum Prymasa Polski, zeszyt 1, b.pag.

${ }^{21}$ Tamże.

${ }^{22}$ AAG, AKM I, sygn. 1823, k. 3. 
go, jak i wspomniany już fakt odnalezienia w katedrze gnieźnieńskiej wojennego archiwum prymasa Augusta Hlonda. Nie od razu zabrano się jednak do ich opracowania. Niewielki zespół pracowników merytorycznych instytucji, obejmujący trzy osoby (ks. Władysława Ziętarskiego, ks. Mariana Aleksandrowicza oraz Jadwigę Rył), sprawił, że prace inwentaryzacyjne (i w pewnym sensie również konserwatorskie) musiały zostać odłożone do 1975 r. Dopiero wówczas, na przełomie października i listopada, ks. Marian Aleksandrowicz podjął się wstępnych prac związanych $\mathrm{z}$ opracowaniem zespołu ${ }^{23}$. Posuwały się one jednak powoli, gdyż Archiwum Prymasa Polski znajdowało się w katastrofalnym stanie. Akta w znacznej mierze były wymieszane, a złe warunki ich przechowywania podczas wojny sprawiły, że niejednokrotnie były one zawilgocone (lub nawet zalane) oraz zagrzybione. Należało zatem najpierw je scalić, a następnie skatalogować i nadać im sygnatury, tak by całość odzwierciedlała przedwojenny system kancelaryjny prymasa Polski. Prace w tym zakresie trwają nadal. Należy bowiem zaznaczyć, że w Archiwum Archidiecezjalnym w Gnieźnie znajduje się jeszcze ok. 7 m.b. akt przynależnych do tego zespołu, które nie zostały opracowane. Zasadniczo są to archiwalia obejmujące sprawy $z$ lat wojennych i powojennych, chociaż można odnaleźć wśród nich i pojedyncze akta odnoszące się do okresu międzywojennego.

Archiwalia z Archiwum Prymasa Polski z okresu międzywojennego zostały w latach 2002-2013 przepakowane do nowych teczek kartonowo-płóciennych zachowujących oryginalne opisy oraz zawartość. Teczki te zostały wykonane w pracowni introligatorskiej funkcjonującej w Archiwum Archidiecezjalnym w Gnieźnie ${ }^{24}$. Było to podyktowane wcześniejszymi sugestiami ks. Mariana Aleksandrowicza, który opracowując Archiwum Prymasa Polski już w 1980 r. zwrócił uwagę, że

Akta wymagają usztywnienia. Teczki, jakie zrobione zostały w Sekretariacie Prymasa Polski w Warszawie są efektowne, ale nie spełniają swojego zadania; są bowiem wykonane z cienkiej tektury, na skutek czego po dłuższym składaniu na półce dolna część akt rozwija się. Trzeba je koniecznie usztywnić przy pomocy związanych teczek zrobionych z grubej i twardej tektury ${ }^{25}$.

Obecne rozwiązanie, będąc realizacją postulatu ks. Mariana Aleksandrowicza, zapewnia Archiwum Prymasa Polski właściwą ochronę, tym bardziej, że akta w nim zgromadzone są typowymi luzami w teczkach.

Istotną uwagą odnoszącą się do sprawy opracowania zespołu Archiwum Prymasa Polski jest kwestia sygnowania akt. W trakcie opracowywania zespołu sygnatury poszczególnym jednostkom nadawał ks. Marian Aleksandrowicz. Jednakże w 2002 r., gdy wprowadzono w Archiwum Archidiecezjalnym w Gnieźnie system katalogowania $\mathrm{w}$ formie elektronicznej, należało ze względów praktycznych nadać im nowe sygnatury, które odpowiadałyby zainstalowanemu syste-

${ }^{23}$ AAG, Archiwum Sekretariatu Archiwum Archidiecezjalnego w Gnieźnie, Księga zajęć 2 IX 1973 - 17 IV 1977, b. pag. (od 27 X 1975 r.).

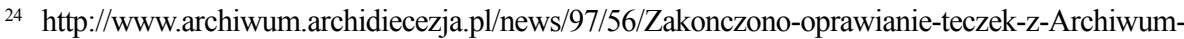
-Prymasa-Polski.html (dostęp: 24.06.2017).

${ }^{25}$ AAG, Archiwum Sekretariatu Archiwum Archidiecezjalnego w Gnieźnie, Notatki ks. Mariana Aleksandrowicza do katalogu Archiwum Prymasa Polski, zeszyt 1, b.pag. 
mowi informatycznemu. Zarówno stare, jak i nowe sygnatury (wprowadzone po 2002 r.) umożliwiają łatwą identyfikację poszukiwanych jednostek archiwalnych.

$* * * * *$

\section{INWENTARZ ZESPOLU ARCHIWUM PRYMASA POLSKI W ZASOBIE ARCHIWUM ARCHIDIECEZJALNEGO W GNIEŹNIE}

Dzial I: Prymas Polski (APP I)

\begin{tabular}{|c|c|c|c|}
\hline $\begin{array}{c}\text { Obecna } \\
\text { sygn. }\end{array}$ & Tytul jednostki & Lata skrajne & Stara sygn. \\
\hline 1 & Unia Kościołów & $1920-1939$ & $1 / 1$ \\
\hline 2 & Unia Kościołów & 1938-1939 & $1 / 2$ \\
\hline 3 & Kościół katolicki obrządku greckiego & $1862-1939$ & 2 \\
\hline 4 & Kościół katolicki obrządku wschodniego & 1926-1939 & 3 \\
\hline 5 & Konkordat Stolicy Apostolskiej z RP. Pertraktacje & 1919-1924 & $4 / 3$ \\
\hline 6 & Konkordat Stolicy Apostolskiej z RP. Pertraktacje & 1921-1938 & $4 / 2$ \\
\hline 7 & Konkordat Stolicy Apostolskiej z RP. Pertraktacje & $1925-1929$ & $4 / 4$ \\
\hline 8 & Konkordat Stolicy Apostolskiej z RP. Pertraktacje & 1930-1939 & $4 / 1$ \\
\hline 9 & Catholica Unio & 1926-1932 & 5 \\
\hline 10 & Union Catholique Internationale de Service Social & 1925-1939 & 6 \\
\hline 11 & Slavia Catholica & 1928-1939 & 7 \\
\hline 12 & Union Catholique d' Etudes Internationales & $1926-1935$ & 8 \\
\hline 13 & Majątek kościelny & $1917-1938$ & 9 \\
\hline 14 & Ministerstwo Wyznań i Oświecenia Publicznego & $1927-1938$ & 10 \\
\hline 15 & Polityka & $1927-1937$ & 11 \\
\hline 16 & Polityka & 1929-1937 & 12 \\
\hline 17 & Konstytucja RP & 1921-1937 & 13 \\
\hline 18 & Akcja Katolicka & $1920-1938$ & $14 / 1$ \\
\hline 19 & Akcja Katolicka & $1923-1938$ & $14 / 2$ \\
\hline 20 & Naczelny Instytut Akcji Katolickiej. Generalia & $1928-1937$ & 15 \\
\hline 21 & $\begin{array}{l}\text { Naczelny Instytut Akcji Katolickiej. Zjazdy i kursy } \\
\text { dla dyrektorów Diecezjalnego Instytutu Akcji } \\
\text { Katolickiej }\end{array}$ & $1930-1936$ & 16 \\
\hline 22 & Komisja Episkopatu Polski d/s społecznych & 1929 & 17 \\
\hline 23 & Akcja społeczna & $1928-1938$ & $18 / 1$ \\
\hline 24 & Akcja społeczna & 1908-1938 & $18 / 2$ \\
\hline 25 & Rada Społeczna & 1929-1939 & 19 \\
\hline 26 & Statuty organizacji katolickich & 1919-1934 & $20 / 1$ \\
\hline 27 & Statuty organizacji katolickich & $1919-1935$ & $20 / 2$ \\
\hline 28 & Ustawa małżeńska (dot. małżeństw cywilnych) & $1920-1933$ & 21 \\
\hline 29 & Kancjonał & 1911-1931 & 22 \\
\hline 30 & Muzyka kościelna & $1917-1938$ & 23 \\
\hline 31 & Liturgia & $1923-1938$ & 24 \\
\hline
\end{tabular}




\begin{tabular}{|c|c|c|c|}
\hline $\begin{array}{c}\text { Obecna } \\
\text { sygn. }\end{array}$ & Tytul jednostki & Lata skrajne & Stara sygn. \\
\hline 32 & Śpiewnik kościelny & 1919-1938 & 25 \\
\hline 33 & Komisja Szkolna Episkopatu Polski & 1919-1939 & 26 \\
\hline 34 & Szkolnictwo polskie. Nauka religii & 1919-1933 & $27 / 1$ \\
\hline 35 & Szkolnictwo polskie. Nauka religii & $1934-1936$ & $27 / 2$ \\
\hline 36 & Szkolnictwo polskie. Nauczanie religii 1937-1938 & $1937-1938$ & $27 / 3$ \\
\hline 37 & Wychowanie państwowe & $\begin{array}{c}1929 \\
1933-1937\end{array}$ & 28 \\
\hline 38 & Duszpasterstwo akademickie & 1937-1939 & 29 \\
\hline 39 & Mniejszości narodowe w Polsce & 1926-1937 & 30 \\
\hline 40 & Kościół i hospicjum św. Stanisława w Rzymie & 1909-1938 & 31 \\
\hline 41 & Papieskie Kolegium Polskie w Rzymie & 1919-1939 & 32 \\
\hline 42 & Papieski Instytut Polski w Rzymie & 1924-1939 & 33 \\
\hline 43 & $\begin{array}{l}\text { Korespondencja rektora Instytutu Polskiego } \\
\text { w Rzymie z Prymasem Polski }\end{array}$ & $1930-1932$ & $33 \mathrm{a}$ \\
\hline 44 & Uniwersytety zagraniczne & $1923-1936$ & 34 \\
\hline 45 & Patronaty kościelne & 1920,1938 & 35 \\
\hline 46 & Instytut Misyjny w Lublinie & $1923-1936$ & 36 \\
\hline 47 & Rycerze Kolumba & $1923-1936$ & 37 \\
\hline 48 & Związek Harcerstwa Polskiego & 1923-1939 & 38 \\
\hline 49 & Związek Harcerstwa Polskiego. Załączniki & 1923-1937 & 39 \\
\hline 50 & Katolicki Związek Kobiet & 1934-1939 & 40 \\
\hline 51 & Katolicki Związek Kobiet & 1927-1939 & 41 \\
\hline 52 & Zjednoczenie Katolickich Związków Polek & 1922-1934 & 42 \\
\hline 53 & Verband Deutscher Katholiken in Polen & 1924-1937 & 43 \\
\hline 54 & Związek Młodzieży Ludowej Wiejskiej & 1927-1939 & 44 \\
\hline 55 & $\begin{array}{l}\text { Zakłady kościelne opieki i wychowania w Polsce. } \\
\text { Nadzór państwa }\end{array}$ & $\begin{array}{c}1926-1933 \\
1938\end{array}$ & 45 \\
\hline 56 & Katolicki Związek Młodzieży Męskiej & 1934-1936 & 46 \\
\hline 57 & Katolicki Związek Młodzieży Męskiej & $1937-1939$ & 47 \\
\hline 58 & Katolicki Związek Młodzieży Męskiej & 1934-1938 & 48 \\
\hline 59 & Zjednoczenie Młodzieży Polskiej & $1930-1931$ & 49 \\
\hline 60 & Zjednoczenie Młodzieży Polskiej & $1932-1933$ & 50 \\
\hline 61 & Zjednoczenie Młodzieży Polskiej & $1933-1934$ & 51 \\
\hline 62 & Zjednoczenie Młodzieży Polskiej & $1930-1935$ & $51 \mathrm{a}$ \\
\hline 63 & Katolicki Związek Mężów & 1934-1939 & 52 \\
\hline 64 & Instytut Wyższej Kultury Religijnej w Polsce & 1937-1939 & 53 \\
\hline 65 & Uniwersytety ludowe & 1938 & 54 \\
\hline 66 & Instytuty Naukowego Badania Komunizmu & 1929 & 55 \\
\hline 67 & $\begin{array}{l}\text { Stronnictwa i organizacje polityczne a Kościół } \\
\text { katolicki }\end{array}$ & $1926-1938$ & 56 \\
\hline 68 & Legion Młodych „Straż Przednia” & $1932-1938$ & 57 \\
\hline 69 & $\begin{array}{l}\text { Fundacja potulicka im. Anieli hr. Potulickiej } \\
\text { na utrzymanie KUL }\end{array}$ & $1926-1939$ & 58 \\
\hline
\end{tabular}




\begin{tabular}{|c|c|c|c|}
\hline $\begin{array}{l}\text { Obecna } \\
\text { sygn. }\end{array}$ & Tytul jednostki & Lata skrajne & Stara sygn \\
\hline 70 & Zatargi. Varia & 1929-1939 & 59 \\
\hline 71 & Nuncjatura apostolska w Polsce & 1918-1939 & 60 \\
\hline 72 & $\begin{array}{l}\text { Akta osobiste prywatne J. Emin. Edmunda kard. } \\
\text { Dalbora }\end{array}$ & $1888-1922$ & 61 \\
\hline 73 & $\begin{array}{l}\text { Akta osobiste prywatne J. Emin. Edmunda kard. } \\
\text { Dalbora }\end{array}$ & $1923-1926$ & $61 / 2$ \\
\hline 74 & J. Em. Edmund Dalbor. Kondolencje & $1915-1926$ & 62 \\
\hline 75 & $\begin{array}{l}\text { Kard. Edmund Dalbor. Odznaczenia godnością } \\
\text { kardynalską }\end{array}$ & $1919-1920$ & 63 \\
\hline 76 & Listy pasterskie i orędzia Episkopatu Polski & 1936-1939 & 64 \\
\hline 77 & Listy Ojca Św. do Episkopatu Polski & $\begin{array}{c}1918-1935 \\
1937\end{array}$ & 65 \\
\hline 78 & Wnioski o audiencję u kard. E. Dalbora & $1915-1925$ & $66 / 1$ \\
\hline 79 & Wnioski o audiencję & 1926-1939 & $66 / 2$ \\
\hline 80 & $\begin{array}{l}\text { Em. August kard. Hlond. Odznaczenie godnością } \\
\text { kardynalską }\end{array}$ & $1927-1928$ & 67 \\
\hline 81 & Tytuł i przywileje Prymasa Polski & 1919-1938 & 68 \\
\hline 82 & Order „Orła Białego” & 1921-1939 & 69 \\
\hline 83 & Adresy hołdownicze & 1921-1929 & $70 / 1$ \\
\hline 84 & Adresy hołdownicze & $\begin{array}{c}1930 \\
1932-1935\end{array}$ & $70 / 2$ \\
\hline 85 & Adresy hołdownicze. Archidiecezja gnieźnieńska & 1919-1935 & $70 / 3$ \\
\hline 86 & Adresy hołdownicze. Archidiecezja poznańska & 1920-1935 & $70 / 4$ \\
\hline 87 & Kard. August Hlond. Korespondencja & 1926-1939 & $70 / 5$ \\
\hline 88 & J. Em. August kard. Hlond. Życzenia & $1925-1926$ & $71 / 1$ \\
\hline 89 & J. Em. August kard. Hlond. Życzenia & 1927 & $71 / 2$ \\
\hline 90 & Kard. A. Hlond. Życzenia & 1928-1929 & $71 / 3$ \\
\hline 91 & Kard. A. Hlond. Życzenia & 1930-1931 & $71 / 4$ \\
\hline 92 & Kard. A. Hlond. Życzenia & 1932-1934 & $72 / 1$ \\
\hline 93 & Kard. A. Hlond. Życzenia & $1935-1936$ & $72 / 2$ \\
\hline 94 & Kard. A. Hlond. Życzenia & 1937 & $72 / 3$ \\
\hline 95 & Kard. A. Hlond. Życzenia & 1937 & $72 / 4$ \\
\hline 96 & Kard. A. Hlond. Życzenia i telegramy & 1926 & $72 / 5$ \\
\hline 97 & Kard. A. Hlond. Życzenia i telegramy & $1927-1928$ & $72 / 6$ \\
\hline 98 & Kard. A. Hlond. Życzenia i telegramy & $1929-1937$ & $72 / 7$ \\
\hline 99 & Kard. A. Hlond. Kondolencje & 1926-1931 & $73 / 1$ \\
\hline 100 & Kard. A. Hlond. Kondolencje & 1933-1934 & $73 / 2$ \\
\hline 101 & J. Em. August kard. Hlond. Zaproszenia & 1926-1929 & $74 / 1$ \\
\hline 102 & J. Em. August kard. Hlond. Zaproszenia & $\begin{array}{c}1930-1932 \\
1934\end{array}$ & $74 / 2$ \\
\hline 103 & J. Em. August kard. Hlond. Zaproszenia & 1936-1938 & $74 / 3$ \\
\hline 104 & $\begin{array}{l}\text { Jubileusz 10-lecia J. Em. Augusta kard. Hlonda. } \\
\text { Odgłosy prasy }\end{array}$ & 1936 & $75 / 1$ \\
\hline
\end{tabular}




\begin{tabular}{|c|c|c|c|}
\hline $\begin{array}{l}\text { Obecna } \\
\text { sygn. }\end{array}$ & Tytul jednostki & Lata skrajne & Stara sygn. \\
\hline 105 & $\begin{array}{l}\text { Jubileusz 10-lecia ingresu J. Em. Augusta kard. } \\
\text { Hlonda }\end{array}$ & 1936 & $75 / 2$ \\
\hline 106 & Jubileusz 10-lecia J. Em. kard. [A.] Hlonda & $1936-1937$ & $75 / 3$ \\
\hline 107 & $\begin{array}{l}\text { Jubileusz 25-lecia kapłaństwa J. Em. Augusta kard. } \\
\text { Hlonda. Życzenia }\end{array}$ & 1930 & $76 / 1$ \\
\hline 108 & $\begin{array}{l}\text { Jubileusz 25-lecia kapłaństwa j. Em. Augusta kard. } \\
\text { Hlonda. Życzenia }\end{array}$ & 1930 & $76 / 2$ \\
\hline 109 & $\begin{array}{l}\text { Jubileusz 25-lecia kapłaństwa J. Em. Augusta kard. } \\
\text { Hlonda. Życzenia }\end{array}$ & 1930 & $76 / 3$ \\
\hline 110 & $\begin{array}{l}\text { Jubileusz 25-lecia kapłaństwa J. Em. Augusta kard. } \\
\text { Hlonda. Odgłosy prasy }\end{array}$ & 1930 & $76 / 4$ \\
\hline 111 & Konklawe & 1939 & 77 \\
\hline 112 & Przyjazdy i przyjęcia dostojników & $1923-1938$ & 78 \\
\hline 113 & Misje zagraniczne & 1928-1939 & 79 \\
\hline 114 & Wycieczki do Polski & $1927-1938$ & 80 \\
\hline 115 & Wycieczki Polaków do Polski z zagranicy & $1925-1938$ & 81 \\
\hline 116 & Biura podróży & 1931-1939 & 82 \\
\hline 117 & Międzynarodowe kongresy eucharystyczne & $1921-1936$ & 83 \\
\hline 118 & Międzynarodowy Kongres Eucharystyczny w Polsce & $1930-1939$ & 84 \\
\hline 119 & $\begin{array}{l}\text { Międzynarodowy Kongres Filozofii Tomistycznej } \\
\text { w Poznaniu }\end{array}$ & $1933-1935$ & 85 \\
\hline 120 & $\begin{array}{l}\text { Międzynarodowy Kongres Eucharystyczny } \\
\text { w Buenos Aires }\end{array}$ & $1933-1936$ & 86 \\
\hline 121 & $\begin{array}{l}\text { Międzynarodowy Kongres Chrystusa Króla } \\
\text { w Poznaniu }\end{array}$ & 1937 & 87 \\
\hline 122 & $\begin{array}{l}\text { Międzynarodowy Kongres Chrystusa Króla } \\
\text { w Poznaniu. Odgłosy prasy }\end{array}$ & $1937-1938$ & $88 \mathrm{a}$ \\
\hline 123 & $\begin{array}{l}\text { Międzynarodowy Kongres Chrystusa Króla } \\
\text { w Poznaniu. Odgłosy prasy }\end{array}$ & $1936-1937$ & $88 \mathrm{~b}$ \\
\hline 124 & $\begin{array}{l}\text { Międzynarodowy Kongres Chrystusa Króla } \\
\text { w Poznaniu. Odgłosy prasy }\end{array}$ & $1937-1938$ & $88 \mathrm{c}$ \\
\hline 125 & $\begin{array}{l}\text { Międzynarodowy Kongres Chrystusa Króla } \\
\text { w Poznaniu. Odgłosy prasy }\end{array}$ & $1934-1937$ & $88 \mathrm{~d}$ \\
\hline 126 & $\begin{array}{l}\text { Międzynarodowy Kongres Eucharystyczny } \\
\text { w Buenos Aires }\end{array}$ & 1934 & 89 \\
\hline 127 & $\begin{array}{l}\text { Międzynarodowy Kongres Eucharystyczny } \\
\text { w Buenos Aires }\end{array}$ & 1934-1935 & $89 \mathrm{a}$ \\
\hline 128 & $\begin{array}{l}\text { Międzynarodowy Kongres Eucharystyczny } \\
\text { w Dublinie }\end{array}$ & $1931-1933$ & $90 \mathrm{a}$ \\
\hline 129 & $\begin{array}{l}\text { Międzynarodowy Kongres Eucharystyczny } \\
\text { w Dublinie. Załączniki }\end{array}$ & $1931-1933$ & $90 \mathrm{~b}$ \\
\hline 130 & $\begin{array}{l}\text { Pielgrzymka Polska do Dublina [na Międzynarodowy } \\
\text { Kongres Eucharystyczny] }\end{array}$ & $1931-1934$ & 91 \\
\hline
\end{tabular}




\begin{tabular}{|c|c|c|c|}
\hline $\begin{array}{l}\text { Obecna } \\
\text { sygn. }\end{array}$ & Tytul jednostki & Lata skrajne & Stara sygn. \\
\hline 131 & $\begin{array}{l}\text { Kard. A. Hlond. Legacja papieska na Kongres } \\
\text { Eucharystyczny w Lublanie }\end{array}$ & $1934-1937$ & 92 \\
\hline 132 & $\begin{array}{l}\text { Kard. A. Hlond. Udział w I Kongresie katolików } \\
\text { czechosłowackich w Pradze }\end{array}$ & 1935 & $92 \mathrm{a}$ \\
\hline 133 & $\begin{array}{l}\text { Międzynarodowy Kongres Chrystusa Króla } \\
\text { w Lublianie }\end{array}$ & $1938-1939$ & 93 \\
\hline 134 & $\begin{array}{l}\text { Międzynarodowy Kongres Przeciwalkoholowy } \\
\text { w Warszawie }\end{array}$ & $1936-1937$ & 94 \\
\hline 135 & $\begin{array}{l}\text { Międzynarodowy Kongres Eucharystyczny } \\
\text { w Budapeszcie }\end{array}$ & $1936-1939$ & 95 \\
\hline 136 & $\begin{array}{l}\text { Międzynarodowy Kongres Eucharystyczny } \\
\text { w Budapeszcie. Załączniki }\end{array}$ & 1936,1938 & $95 \mathrm{a}$ \\
\hline 137 & Międzynarodowy Kongres Eucharystyczny w Manili & $1936-1937$ & $96 \mathrm{a}$ \\
\hline 138 & Międzynarodowy Kongres Eucharystyczny w Manili & 1936-1939 & 96 \\
\hline 139 & Zjazdy i uroczystości w Austrii & $1927-1938$ & $97 \mathrm{a}$ \\
\hline 140 & Zjazdy i uroczystości katolików w Austrii. Załączniki & $1927-1938$ & $97 \mathrm{~b}$ \\
\hline 141 & Zjazdy i uroczystości katolików w Niemczech & $1920-1936$ & 98 \\
\hline 142 & $\begin{array}{l}\text { Uroczystości zamknięcia Jubileuszu Odkupienia } \\
\text { w Lourdes }\end{array}$ & $1932-1935$ & 99 \\
\hline 143 & Biuro Episkopatu Polski & 1922-1938 & 100 \\
\hline 144 & Komisja Unionistyczna Episkopatu Polski & 1929 & 101 \\
\hline 145 & $\begin{array}{l}\text { Komisja Episkopatu Polski do spraw fundacyjnych } \\
\text { i charytatywnych }\end{array}$ & 1937 & 102 \\
\hline 146 & Komisja Liturgiczna Episkopatu Polski (przed 1932) & 1932 & 103 \\
\hline 147 & Komisja Papieska Episkopatu Polski & $1920-1936$ & 104 \\
\hline 148 & Komisja Prawna Episkopatu Polski & 1928-1939 & 105 \\
\hline 149 & Komisja Prasowa Episkopatu Polski & 1921-1939 & 106 \\
\hline 150 & $\begin{array}{l}\text { Komisja Episkopatu Polski dla duszpasterstwa } \\
\text { zagranicznego }\end{array}$ & $1920-1929$ & 107 \\
\hline 151 & $\begin{array}{l}\text { Komisja Episkopatu Polski dla spraw Akcji } \\
\text { Katolickiej }\end{array}$ & $1928-1939$ & 108 \\
\hline 152 & Komisja Synodalna Episkopatu Polski & 1936-1937 & $109 \mathrm{a}$ \\
\hline 153 & Komisja Synodalna Episkopatu Polski. Załączniki & 1936 & $109 \mathrm{~b}$ \\
\hline 154 & Episkopat Polski. Personalne sprawy & 1923-1939 & 110 \\
\hline 155 & Konferencja Plenarna Episkopatu Polski & 1918-1919 & $111 \mathrm{a}$ \\
\hline 156 & Konferencje Plenarne Episkopatu Polski & 1923-1924 & $111 \mathrm{~b}$ \\
\hline 157 & Konferencje Plenarne Episkopatu Polski & $\begin{array}{c}1927 \\
1929-1932\end{array}$ & $111 \mathrm{c}$ \\
\hline 158 & Konferencje Plenarne Episkopatu Polski & $1937-1939$ & $111 \mathrm{~d}$ \\
\hline 159 & Protokoły konferencji plenarnych Episkopatu Polski & $1919-1925$ & 112 \\
\hline 160 & Polski Synod Plenarny & $1929-1936$ & $113 \mathrm{a}$ \\
\hline 161 & Synod Plenarny Polski & 1937-1939 & $113 \mathrm{~b}$ \\
\hline 162 & Synod Plenarny Polski z 1936 & 1934-1938 & $113 \mathrm{c}$ \\
\hline 163 & Synod Plenarny Polski z 1936 r. Druki & $1936-1938$ & $113 \mathrm{~d}$ \\
\hline
\end{tabular}




\begin{tabular}{|c|c|c|c|}
\hline $\begin{array}{l}\text { Obecna } \\
\text { sygn. }\end{array}$ & Tytul jednostki & Lata skrajne & Stara sygn. \\
\hline 164 & Unia Apostolska & $1937-1938$ & 114 \\
\hline 165 & Zakon Służby Bożej w narodzie polskim & 1929-1937 & 115 \\
\hline 166 & Zakłady lecznicze. Szpitale & 1930-1939 & 116 \\
\hline 167 & Ustawa o składkach na rzecz Kościoła katolickiego & 1928-1937 & 117 \\
\hline 168 & Reforma rolna. Parcelacja dóbr kościelnych & 1931-1939 & 118 \\
\hline 169 & Pałac prymasowski w Warszawie & $\begin{array}{c}1909 \\
1921-1932\end{array}$ & 119 \\
\hline 170 & Katolicki Uniwersytet w Lublinie & $1920-1927$ & $120 \mathrm{a}$ \\
\hline 171 & Katolicki Uniwersytet w Lublinie & $1928-1932$ & $120 \mathrm{~b}$ \\
\hline 172 & Katolicki Uniwersytet w Lublinie & 1933-1939 & $120 \mathrm{c}$ \\
\hline 173 & Katolicki Uniwersytet w Lublinie. Aneksy & 1920-1939 & $120 \mathrm{~d}$ \\
\hline 174 & Seminaria duchowne & 1933-1937 & 121 \\
\hline 175 & Papieskie Seminarium Wschodnie w Dubnie & 1931-1938 & 122 \\
\hline 176 & Seminarium Duchowne w Gnieźnie & 1922-1939 & 123 \\
\hline 177 & Audytor Polski św. Roty & 1920-1939 & 124 \\
\hline 178 & Krucjata Eucharystyczna & $1927-1939$ & 125 \\
\hline 179 & Ambasada Polska przy Stolicy Apostolskiej & 1919-1938 & 126 \\
\hline 180 & Liga Narodów & $1927-1938$ & 127 \\
\hline 181 & Duszpasterstwo wojskowe & 1919-1939 & 129 \\
\hline 182 & Duszpasterstwo Niemców-katolików & $1927-1934$ & $130 \mathrm{a}$ \\
\hline 183 & Duszpasterstwo Niemców-katolików & 1936-1939 & $130 \mathrm{~b}$ \\
\hline 184 & $\begin{array}{l}\text { Duszpasterstwo Niemców-katolików. Druki } \\
\text { i wycinki gazetowe }\end{array}$ & 1926-1936 & $130 \mathrm{c}$ \\
\hline 185 & Diecezja katowicka & 1919-1934 & $131 \mathrm{a}$ \\
\hline 186 & Diecezja katowicka & 1928-1939 & $131 \mathrm{~b}$ \\
\hline 187 & Generalny Komisariat Ziemi Świętej & $1909-1936$ & 132 \\
\hline 188 & $\begin{array}{l}\text { Kard. A. Hlond. Kościół tytularny Matki Bożej della } \\
\text { Pace w Rzymie }\end{array}$ & $1927-1934$ & 133 \\
\hline 189 & Miscellanea & 1938-1939 & 134 \\
\hline 190 & Korespondencja księży biskupów (Varia) & 1919-1935 & 135 \\
\hline 191 & Wychowanie państwowe & 1934,1938 & 136 \\
\hline 192 & Wycieczki z Polski & 1933-1939 & 137 \\
\hline 193 & $\begin{array}{l}\text { Protest przeciw prześladowaniom religii katolickiej } \\
\text { w ZSRR i Meksyku }\end{array}$ & $1923-1930$ & $137 \mathrm{a}$ \\
\hline 194 & Beatyfikacja Stanisława kard. Hozjusza & 1926-1938 & 138 \\
\hline 195 & Beatyfikacja królowej Jadwigi & $1932-1938$ & 139 \\
\hline 196 & Objawienia w Słupi Wielkiej & 1926-1936 & 140 \\
\hline 197 & Francja. Wizyta kard. Hlonda w 1936 r. & $1935-1937$ & 141 \\
\hline 198 & Pacyfizm i rozbrojenie & $1927-1938$ & 142 \\
\hline 199 & Walka z Kościołem & $1922-1938$ & 143 \\
\hline 200 & Walka z Kościołem w Niemczech & $1922-1936$ & 144 \\
\hline 201 & Walka z Kościołem w Niemczech & 1937-1939 & $144 \mathrm{~b}$ \\
\hline 202 & Walka z Kościołem w ZSRR & $1922-1937$ & $144 \mathrm{c}$ \\
\hline
\end{tabular}




\begin{tabular}{|c|c|c|c|}
\hline $\begin{array}{l}\text { Obecna } \\
\text { sygn. }\end{array}$ & Tytul jednostki & Lata skrajne & Stara sygn. \\
\hline 203 & Prześladowania Kościoła w Meksyku & $1927-1937$ & $144 d$ \\
\hline 204 & Prześladowanie Kościoła w Hiszpanii & 1931-1937 & $144 \mathrm{e}$ \\
\hline 205 & Korespondencja. Varia & 1924-1939 & 145 \\
\hline 206 & $\begin{array}{l}\text { Katolicki Związek Zakładów Wychowawczych } \\
\text { i Opiekuńczych }\end{array}$ & $1930-1931$ & 146 \\
\hline 207 & Liga Morska i Kolonialna & 1931-1939 & 147 \\
\hline 208 & Korespondencja z o. Efremem Klawitterem & 1930-1939 & 148 \\
\hline 209 & Korespondencja ks. Jana Korzonkiewicza & $1927-1934$ & 149 \\
\hline 210 & Korespondencja prof. dr Stefana Dąbrowskiego & 1926-1939 & 150 \\
\hline 211 & Program nauki religii w szkołach & 1933-1938 & 151 \\
\hline 212 & Beatyfikacja ks. Piotra Skargi & 1934 & 152 \\
\hline 213 & „Kultura” - Tygodnik Katolicki & 1936-1938 & 153 \\
\hline 214 & Testament śp. Marka Emanuela Małyńskiego & 1937-1939 & 154 \\
\hline 215 & Nagroda im. prof. Tadeusza Chrząszcza & $1935-1937$ & 155 \\
\hline 216 & Zatarg wawelski & 1937 & 156 \\
\hline 217 & Korespondencja księży biskupów. Varia & 1929-1939 & 157 \\
\hline 218 & Prasa katolicka. Varia & 1919-1938 & 158 \\
\hline 219 & Totalitaryzm & $1937-1938$ & 159 \\
\hline 220 & Rasizm & 1933-1938 & 160 \\
\hline 221 & Rotary Club & $1930-1938$ & 161 \\
\hline 222 & Masoneria & $1923-1937$ & 162 \\
\hline 223 & $\begin{array}{l}\text { [Księga przychodów i rozchodów kasy kancelarii } \\
\text { Prymasa Polski] }\end{array}$ & 1932 & - \\
\hline 224 & $\begin{array}{l}\text { [Księga przychodów i rozchodów kasy kancelarii } \\
\text { Prymasa Polski] }\end{array}$ & 1934 & - \\
\hline 225 & $\begin{array}{l}\text { [Księga przychodów i rozchodów kasy kancelarii } \\
\text { Prymasa Polski] }\end{array}$ & 1938 & - \\
\hline 226 & [Księga dochodów i rozchodów za metryki] & $1929-1930$ & - \\
\hline 227 & Osobiste prywatne J. Em. Augusta kard. Hlonda & $1929-1938$ & - \\
\hline 228 & Osobiste prywatne J. Em. Augusta kard. Hlonda & 1938-1939 & - \\
\hline
\end{tabular}

\section{Dział II: Ordynariat (APP II)}

\begin{tabular}{|c|l|c|c|}
\hline $\begin{array}{c}\text { Obecna } \\
\text { sygn. }\end{array}$ & \multicolumn{1}{|c|}{ Tytul jednostki } & Lata skrajne & Stara sygn. \\
\hline 1 & Pałac arcybiskupi w Gnieźnie & $1846-1939$ & 1 \\
\hline 2 & $\begin{array}{l}\text { Kolegiata i kapituła kolegiaty Św. Marii Magdaleny } \\
\text { w Poznaniu }\end{array}$ & $1928-1939$ & 2 \\
\hline 3 & Kościół oo. Franciszkanów w Poznaniu & $1933-1938$ & 3 \\
\hline 4 & Bazylika gnieźnieńska & $1928-1938$ & 4 \\
\hline 5 & $\begin{array}{l}\text { Kolegiata i kapituła kolegiaty św. Piotra i Pawła } \\
\text { w Kruszwicy }\end{array}$ & $1928-1939$ & 5 \\
\hline 6 & Komisja mieszana konserwatorska & $1925-1934$ & 6 \\
\hline
\end{tabular}




\begin{tabular}{|c|c|c|c|}
\hline $\begin{array}{l}\text { Obecna } \\
\text { sygn. }\end{array}$ & Tytul jednostki & Lata skrajne & Stara sygn. \\
\hline 7 & Kolegiata św. Jerzego w Gnieźnie & $1925-1937$ & 7 \\
\hline 8 & Zabytki kościelne & 1927 & 8 \\
\hline 9 & $\begin{array}{l}\text { Inkorporacja beneficjum w Krobi stolicy } \\
\text { arcybiskupiej w Poznaniu }\end{array}$ & $1927-1937$ & 9 \\
\hline 10 & $\begin{array}{l}\text { Inkorporacja beneficjum w Kamieńcu stolicy } \\
\text { arcybiskupiej w Gnieźnie }\end{array}$ & $1928-1939$ & 10 \\
\hline 11 & Kościoły. Varia & 1919-1939 & 11 \\
\hline 12 & Archiwum i biblioteka archidiecezji poznańskiej & 1924-1939 & 12 \\
\hline 13 & Dotacje i podatki państwowe & $1908-1933$ & $13 \mathrm{a}$ \\
\hline 14 & Dotacje i podatki państwowe & $1836-1908$ & $13 \mathrm{~b}$ \\
\hline 15 & Reforma rolna - parcelacja dóbr kościelnych & $1922-1935$ & 14 \\
\hline 16 & Danina parafialna & $1930-1937$ & 15 \\
\hline 17 & Katolicki Związek Towarzystw Rolników Polskich & $1891-1931$ & 16 \\
\hline 18 & $\begin{array}{l}\text { Rada Wyższa Stowarzyszenia Pań św. Wincentego } \\
\text { a Paulo }\end{array}$ & $1867-1932$ & 17 \\
\hline 19 & $\begin{array}{l}\text { Rada Wyższa Towarzystwa św. Wincentego a Paulo } \\
\text { - Męska }\end{array}$ & $1867-1939$ & 18 \\
\hline 20 & Archidiecezjalny Instytut Akcji Katolickiej & 1924-1937 & 19 \\
\hline 21 & Związek Chórów Kościelnych & 1926-1939 & 20 \\
\hline 22 & Związek Młodych Polek & 1919-1934 & 21 \\
\hline 23 & Katolickie Stowarzyszenie Młodzieży Żeńskiej & 1934-1939 & 22 \\
\hline 24 & $\begin{array}{l}\text { Katolickie Towarzystwo Ochrony Kobiet } \\
\text { w Poznaniu }\end{array}$ & $1925-1938$ & 23 \\
\hline 25 & Katolickie Stowarzyszenie Kobiet & 1934-1939 & 24 \\
\hline 26 & Katolickie Stowarzyszenie Mężów & 1934-1939 & 25 \\
\hline 27 & $\begin{array}{l}\text { Zakłady kościelne opiekuńcze i wychowawczy } \\
\text { nadzór państwowy }\end{array}$ & $1927-1936$ & 26 \\
\hline 28 & Krucjata Eucharystyczna & $1931-1938$ & 27 \\
\hline 29 & Fundusz Obrony Narodowej & 1936-1938 & 28 \\
\hline 30 & Personalia ks. Czesława Bogackiego & $\begin{array}{c}1924 \\
1935-1939 \\
\end{array}$ & 30 \\
\hline 31 & $\begin{array}{l}\text { Personalia i korespondencja Kazimiery } \\
\text { Berkanówny }\end{array}$ & $1926-1939$ & 31 \\
\hline 32 & Personalia ks. Teofila Wachowskiego & 1929-1939 & 32 \\
\hline 33 & Personalia ks. Bronisława Wiertla & $1932-1933$ & 33 \\
\hline 34 & Akta personalne ks. Bernarda Woltmana & 1933-1939 & 34 \\
\hline 35 & Personalia ks. Józefa Jasińskiego & $1927-1939$ & 35 \\
\hline 36 & $\begin{array}{l}\text { Zatarg hr. Hutten-Czapski c/a Kuria Arcybiskupia } \\
\text { w Gnieźnie }\end{array}$ & $1935-1936$ & 36 \\
\hline 37 & $\begin{array}{l}\text { Zatarg o precedencję: kolegiata poznańska c/a } \\
\text { seminarium duchowne }\end{array}$ & $1926-1928$ & 37 \\
\hline 38 & $\begin{array}{l}\text { Zabójstwo śp. ks. Stanisława Streicha. } \\
\text { Odgłosy prasy }\end{array}$ & 1938 & 38 \\
\hline 39 & Testament śp. Anny Skarżyńskiej & $1928-1935$ & 39 \\
\hline
\end{tabular}




\begin{tabular}{|c|c|c|c|}
\hline $\begin{array}{l}\text { Obecna } \\
\text { sygn. }\end{array}$ & Tytul jednostki & Lata skrajne & Stara sygn. \\
\hline 40 & Testament śp. msgr Pawła Gregora & 1931-1937 & 40 \\
\hline 41 & Testament śp. ks. Wojciecha Duczmala & 1937 & 41 \\
\hline 42 & Testament Sławomiry Heleny Śmitkowskiej & $1930-1935$ & 42 \\
\hline 43 & Testament śp. Zygmunta Marwega & 1931-1937 & 43 \\
\hline 44 & Testament ks. Teofila Malkowskiego & 1935 & 44 \\
\hline 45 & Testament bp A. Laubitza & 1939 & 45 \\
\hline 46 & Kapituły Metropolitalne w Gnieźnie i Poznaniu & $1862-1930$ & 46 \\
\hline 47 & Kapituła Metropolitalna w Poznaniu & $\begin{array}{c}1912-1929 \\
1934\end{array}$ & $47 / 3$ \\
\hline 48 & Kapituła Metropolitalna w Poznaniu & 1938-1939 & $47 / 5$ \\
\hline 49 & Pałac arcybiskupi w Gnieźnie & $1921-1938$ & 48 \\
\hline 50 & Kuria Arcybiskupia w Poznaniu & $1925-1938$ & 49 \\
\hline 51 & Sekretariat dla spraw misyjnych & $1926-1937$ & 50 \\
\hline 52 & Orędzia i rozporządzenia abp E. Dalbora & 1916-1925 & $50 / 1$ \\
\hline 53 & Orędzia i rozporządzenia abp A. Hlonda & $1928-1939$ & $51 / 2$ \\
\hline 54 & Listy pasterskie kard. A. Hlonda & $1932-1938$ & $52 / 1$ \\
\hline 55 & $\begin{array}{l}\text { Autografy niektórych orędzi i listów pasterskich } \\
\text { kard. A. Hlonda }\end{array}$ & $1933-1937$ & $52 / 2$ \\
\hline 56 & Listy pasterskie kard. A. Hlonda & 1931-1932 & $52 / 3$ \\
\hline 57 & $\begin{array}{l}\text { Listy pasterskie-administracja } \\
\text { [Kolportaż listów pasterskich] }\end{array}$ & $1932-1936$ & $53 / 1$ \\
\hline 58 & Wywiady kard. A. Hlonda & $1932-1938$ & $53 / 2$ \\
\hline 59 & Podatki beneficjalne i parafialne & 1906-1938 & 54 \\
\hline 60 & Agencja rzymska & 1913-1938 & 55 \\
\hline 61 & Duszpasterstwo wojskowe & 1914-1939 & 56 \\
\hline 62 & Duszpasterstwo uniwersyteckie & 1919-1939 & 57 \\
\hline 63 & Uroczystości papieskie & $1922-1938$ & 58 \\
\hline 64 & Świętopietrze & 1922-1939 & 59 \\
\hline 65 & Duszpasterstwo greko-katolickie & $1930-1935$ & 60 \\
\hline 66 & Duszpasterstwo Niemców-katolików & $1917-1930$ & $61 / \mathrm{a}$ \\
\hline 67 & Duszpasterstwo Niemców katolików & $1930-1936$ & $61 / \mathrm{b}$ \\
\hline 68 & $\begin{array}{l}\text { Sądy metropolitalne w Gnieźnie i Poznaniu. } \\
\text { Generalia }\end{array}$ & $\begin{array}{l}1867-1868 \\
1915-1938\end{array}$ & 62 \\
\hline 69 & Sąd Duchowny w Poznaniu & $1831-1930$ & $63 / \mathrm{a}$ \\
\hline 70 & Sąd Duchowny w Poznaniu & $1931-1936$ & $63 / \mathrm{b}$ \\
\hline 71 & Sąd Duchowny w Poznaniu & 1937-1939 & $63 / \mathrm{c}$ \\
\hline 72 & Sąd Duchowny w Gnieźnie & $1868-1939$ & 64 \\
\hline 73 & Opieka polska nad rodakami na obczyźnie & $\begin{array}{l}1927 \\
1934\end{array}$ & 66 \\
\hline 74 & Katolicki Instytut Wychowawczy & $1930-1937$ & 67 \\
\hline 75 & Instytut Wyższej Kultury Religijnej w Poznaniu & 1934-1939 & 68 \\
\hline 76 & Związek Kapłanów „Unio Apostolich” & $1917-1938$ & 69 \\
\hline 77 & Konwikty arcybiskupie & $1922-1936$ & 70 \\
\hline
\end{tabular}




\begin{tabular}{|c|c|c|c|}
\hline $\begin{array}{l}\text { Obecna } \\
\text { sygn. }\end{array}$ & Tytul jednostki & Lata skrajne & Stara sygn. \\
\hline 78 & Instytut Zasiłkowej Kasy Emerytalnej & 1926-1939 & 71 \\
\hline 79 & Związek Gmin Kościelnych m. Poznania & $1930-1937$ & 72 \\
\hline 80 & Szkolnictwo & 1928-1939 & 73 \\
\hline 81 & Uniwersytet Ludowy na Dalkach w Gnieźnie & $1936-1938$ & 74 \\
\hline 82 & Seminarium Duchowne w Poznaniu & $1835-1846$ & $75 / 1$ \\
\hline 83 & Seminarium Duchowne w Poznaniu & $1845-1856$ & $75 / 2$ \\
\hline 84 & Seminarium Duchowne w Poznaniu & $1890-1915$ & $75 / 4$ \\
\hline 85 & Seminarium Duchowne w Poznaniu & $1922-1935$ & $75 / 6$ \\
\hline 86 & Seminarium Duchowne w Poznaniu & 1936-1938 & $75 / 7$ \\
\hline 87 & $\begin{array}{l}\text { Korespondencja z dyrekcją Drukarni i Księgarni } \\
\text { Św. Wojciecha }\end{array}$ & $1928-1937$ & 76 \\
\hline 88 & Rocznik Archidiecezji Gnieźnieńskiej i Poznańskiej & 1938 & $76 / \mathrm{a}$ \\
\hline 89 & Szpitale - zakłady lecznicze & $1929-1938$ & 77 \\
\hline 90 & Szpital „Przemienienia Pańskiego” w Poznaniu & $1929-1932$ & 78 \\
\hline 91 & Rezerwaty biskupie & 1916-1934 & 79 \\
\hline 92 & Drukarnia - Księgarnia Św. Wojciecha. Generalia & 1929-1939 & 80 \\
\hline 93 & Drukarnia i Księgarnia Św. Wojciecha. Udziałowcy & $1903-1926$ & $81 / \mathrm{a}$ \\
\hline 94 & Drukarnia i Księgarnia Św. Wojciecha. Udziałowcy & $1927-1938$ & $81 / \mathrm{b}$ \\
\hline 95 & $\begin{array}{l}\text { Księgarnia i drukarnia Św. Wojciecha. } \\
\text { Zapotrzebowania }\end{array}$ & $1928-1929$ & 82 \\
\hline 96 & Dyspensy. Generalia & 1924-1939 & 83 \\
\hline 97 & $\begin{array}{l}\text { Dyspensy małżeńskie na mocy facultates } \\
\text { quinquenalia. Sprawozdania }\end{array}$ & $1922-1938$ & 84 \\
\hline 98 & Relacje diecezjalne ad limina Apostolorum & 1926-1938 & 85 \\
\hline 99 & $\begin{array}{l}\text { Seminarium Duchowne w Gnieźnie i Poznaniu. } \\
\text { Generalia }\end{array}$ & 1916-1938 & 86 \\
\hline 100 & $\begin{array}{l}\text { Kuria Arcybiskupia w Gnieźnie i Poznaniu. } \\
\text { Generalia }\end{array}$ & $1925-1938$ & 87 \\
\hline 101 & $\begin{array}{l}\text { Seminarium Duchowne w Gnieźnie i w Poznaniu. } \\
\text { Deputaci w sprawach dyscypliny }\end{array}$ & $1922-1930$ & 88 \\
\hline 102 & $\begin{array}{l}\text { Seminarium Duchowne w Gnieźnie i w Poznaniu. } \\
\text { Czesne }\end{array}$ & 1918-1935 & 89 \\
\hline 103 & Wizytacje kanoniczne parafii & 1927-1939 & 90 \\
\hline 104 & $\begin{array}{l}\text { Wizytacje kanoniczne parafii i instytucji } \\
\text { kościelnych m. Poznania }\end{array}$ & $1931-1939$ & 91 \\
\hline 105 & Zatarg Pryl c/a śp. ks. Szukała & $1928-1936$ & 92 \\
\hline
\end{tabular}




\section{Dzial III: Protektorat Wychodźstwa (APP III)}

\begin{tabular}{|c|c|c|c|}
\hline $\begin{array}{l}\text { Obecna } \\
\text { sygn. }\end{array}$ & Tytuł jednostki & Lata skrajne & Stara sygn. \\
\hline 1 & Instytut Polski Współpracy z Zagranicą. Varia & 1931-1935 & 1 \\
\hline 2 & Sprawy wychodźstwa. Generalia & $\begin{array}{c}1917 \\
1923-1938\end{array}$ & 2 \\
\hline 3 & Opieka polska nad rodakami na obczyźnie & 1931-1939 & 3 \\
\hline 4 & Światowy Związek Polaków z Zagranicy - Varia & $1930-1939$ & 4 \\
\hline 5 & Rada Organizacyjna Polaków z Zagranicy - Varia & 1933-1934 & 5 \\
\hline 6 & Towarzystwo Pomocy Polonii Zagranicznej & 1936-1938 & 6 \\
\hline 7 & Apostolatus Maris & 1929-1939 & 7 \\
\hline 8 & Wystawa „Polska i Polacy w świecie” & 1934 & 8 \\
\hline 9 & $\begin{array}{l}\text { Komitet Wychowania Narodowego Młodzieży } \\
\text { Polskiej z Zagranicy }\end{array}$ & $1932-1935$ & 9 \\
\hline 10 & Szkolnictwo polskie & 1928-1939 & 10 \\
\hline 11 & Budżet. Subwencje. Fundusze & 1926-1939 & 11 \\
\hline 12 & Zjazdy Polaków z zagranicy & $1927-1938$ & 12 \\
\hline 13 & Francja. Budżet. Subwencje. Fundusze & 1922-1939 & 13 \\
\hline 14 & Francja. Polska Misja Katolicka, Varia & $1919-1922$ & 14 \\
\hline 15 & Francja. Polska Misja Katolicka. Varia & 1923 & $14 \mathrm{a}$ \\
\hline 16 & Francja. Polska Misja Katolicka. Varia & 1924 & $15 \mathrm{a}$ \\
\hline 17 & Misja Polska we Francji & $1925-1926$ & $15 \mathrm{~b}$ \\
\hline 18 & Francja. Polska Misja Katolicka & 1927 & $15 \mathrm{c}$ \\
\hline 19 & Francja. Polska Misja Katolicka. Varia & 1928 & 16 \\
\hline 20 & Francja. Polska Misja Katolicka. Varia & 1929-1931 & 17 \\
\hline 21 & Francja. Polska Misja Katolicka. Varia & $1932-1935$ & 18 \\
\hline 22 & Francja. Polska Misja Katolicka & 1936-1937 & $19 \mathrm{a}$ \\
\hline 23 & Francja. Polska Misja Katolicka & 1938-1939 & $19 \mathrm{~b}$ \\
\hline 24 & Francja. Związek Polaków we Francji & 1938 & 20 \\
\hline 25 & Zjazdy polsko-katolickie. Francja & 1930-1939 & 21 \\
\hline 26 & Francja. Wizyta J. E. kard. Hlonda we Francji & 1934 & $22 \mathrm{a}$ \\
\hline 27 & Francja. P[olska] M[isja] K[atolicka]. Varia. & $1929-1931$ & 22 \\
\hline 28 & Francja. Wizyta J. E. kard. Hlonda we Francji & 1934 & $22 b$ \\
\hline 29 & Francja. Szkolnictwo polskie & 1921-1937 & 23 \\
\hline 30 & $\begin{array}{l}\text { Francja. Zjednoczenie Polskich Towarzystw } \\
\text { Katolickich }\end{array}$ & 1923-1939 & $23 \mathrm{a}$ \\
\hline 31 & Francja. Sprawy społeczne & $\begin{array}{c}1923 \\
1928-1933 \\
\end{array}$ & 24 \\
\hline 32 & $\begin{array}{l}\text { Francja. Katolickie Stowarzyszenie Młodzieży } \\
\text { Polskiej }\end{array}$ & $1938-1939$ & 25 \\
\hline 33 & „Polak we Francji” & $1923-1938$ & 26 \\
\hline 34 & Francja. Kościół del Assomption w Paryżu & $\begin{array}{c}1921 \\
1927-1937 \\
\end{array}$ & 27 \\
\hline 35 & Rosja Sowiecka. Varia & $1923-1938$ & 28 \\
\hline 36 & Stany Zjednoczone Ameryki Północnej. Varia & 1904-1927 & 29 \\
\hline
\end{tabular}




\begin{tabular}{|c|c|c|c|}
\hline $\begin{array}{l}\text { Obecna } \\
\text { sygn. }\end{array}$ & Tytul jednostki & Lata skrajne & Stara sygn. \\
\hline 37 & Stany Zjednoczone Ameryki Północnej. Varia & $\begin{array}{c}1926 \\
1928-1932\end{array}$ & 30 \\
\hline 38 & $\begin{array}{l}\text { Stany Zjednoczone Ameryki Północnej. Episkopat } \\
\text { Polski }\end{array}$ & $1922-1938$ & 31 \\
\hline 39 & Stany Zjednoczone Ameryki Północnej. Varia & 1929-1931 & 32 \\
\hline 40 & Stany Zjednoczone Ameryki Północnej & $1932-1935$ & 33 \\
\hline 41 & Stany Zjednoczone Ameryki Północnej & 1937 & 34 \\
\hline 42 & Stany Zjednoczone Ameryki Północnej & 1938 & 35 \\
\hline 43 & Stany Zjednoczone Ameryki Północnej & $1932-1936$ & 36 \\
\hline 44 & $\begin{array}{l}\text { Stany Zjednoczone Ameryki Północnej. } \\
\text { Rada Polska Miedzyorg. }\end{array}$ & 1936 & $37 \mathrm{a}$ \\
\hline 45 & Anglia P[olska] M[isja] K[atolicka]. Generalia & $1927-1938$ & $37 \mathrm{~b}$ \\
\hline 46 & Anglia. Budżet. Fundusze. Subwencje & 1938 & $37 \mathrm{c}$ \\
\hline 47 & Austria & 1938-1939 & 38 \\
\hline 48 & Afryka & 1934 & 39 \\
\hline 49 & Argentyna & 1922-1939 & $40 \mathrm{a}$ \\
\hline 50 & Australia & $1928-1938$ & 41 \\
\hline 51 & Belgia. Wizyta J. E. kard. A. Hlonda & 1936 & 42 \\
\hline 52 & $\begin{array}{l}\text { Akta kancelarii Prymasa Polski w Poznaniu tyczące } \\
\text { się „Strzelca” w Belgii }\end{array}$ & 1932 & 43 \\
\hline 53 & Belgia. Generalia & 1935-1939 & 44 \\
\hline 54 & Belgia. Generalia & $1923-1936$ & $44 \mathrm{a}$ \\
\hline 55 & Czechosłowacja. Generalia & $1927-1938$ & 45 \\
\hline 56 & Czechosłowacja. Szkolnictwo Polskie & $1927-1937$ & 46 \\
\hline 57 & $\begin{array}{l}\text { Belgia. Polska Misja Katolicka. Budżet. Subwencje } \\
\text { państwowe }\end{array}$ & 1932-1939 & 47 \\
\hline 58 & Holandia & $1927-1938$ & 48 \\
\hline 59 & Japonia & 1930-1933 & 49 \\
\hline 60 & Paragwaj & 1932 & 50 \\
\hline 61 & Wolne Miasto Gdańsk. Szkolnictwo polskie & 1926-1937 & 51 \\
\hline 62 & Finlandia & $1927-1937$ & 52 \\
\hline 63 & Ekwador & $1927-1935$ & 53 \\
\hline 64 & Estonia & 1932-1938 & 54 \\
\hline 65 & Chiny. Mandżuria & 1927-1939 & 55 \\
\hline 66 & Włochy. Varia & $1927-1935$ & 56 \\
\hline 67 & $\begin{array}{l}\text { Ziemia Święta. Kaplica polska Św. Antoniego } \\
\text { w Nazarecie }\end{array}$ & $1928-1935$ & 57 \\
\hline 68 & Ziemia Święta. Varia & $1927-1938$ & 58 \\
\hline 69 & $\begin{array}{l}\text { Włochy. Kaplica polska w Loretto w Bazylice } \\
\text { Domku Najświętszej Rodziny }\end{array}$ & $1927-1937$ & 59 \\
\hline 70 & Brazylia & $1927-1934$ & 60 \\
\hline 71 & Brazylia & $1935-1938$ & 61 \\
\hline 72 & Chile & $1927-1936$ & 62 \\
\hline
\end{tabular}




\begin{tabular}{|c|c|c|c|}
\hline $\begin{array}{l}\text { Obecna } \\
\text { sygn. }\end{array}$ & Tytuł jednostki & Lata skrajne & Stara sygn. \\
\hline 73 & Dania & $1922-1933$ & 63 \\
\hline 74 & Dania & 1933-1938 & 64 \\
\hline 75 & Wolne Miasto Gdańsk. Varia & 1921-1939 & 65 \\
\hline 76 & Kuba & $1927-1933$ & 66 \\
\hline 77 & Luksemburg & 1928-1939 & 67 \\
\hline 78 & Meksyk & 1928 & 68 \\
\hline 79 & Urugwaj & $1932-1938$ & 69 \\
\hline 80 & Turcja & $1927-1938$ & 70 \\
\hline 81 & Rumunia. Szkolnictwo polskie & 1931-1939 & 71 \\
\hline 82 & Węgry & 1924-1939 & 73 \\
\hline 83 & $\begin{array}{l}\text { Kursy kultury polskiej dla kleryków i sióstr } \\
\text { zakonnych }\end{array}$ & $1935-1938$ & 74 \\
\hline 84 & Nauka języka polskiego w celach duszpasterskich & $1930-1938$ & 75 \\
\hline 85 & Duszpasterstwo morskie & $1929-1937$ & 76 \\
\hline 86 & $\begin{array}{l}\text { Towarzystwo Chrystusowe dla Wychodźców. } \\
\text { Seminarium Zagraniczne }\end{array}$ & $1927-1934$ & 77 \\
\hline 87 & $\begin{array}{l}\text { Towarzystwo Chrystusowe dla Wychodźców. } \\
\text { Seminarium Zagraniczne }\end{array}$ & $1938-1939$ & 78 \\
\hline 88 & $\begin{array}{l}\text { Towarzystwo Chrystusowe dla Wychodźców. } \\
\text { Generalia }\end{array}$ & $1933-1937$ & 79 \\
\hline 89 & $\begin{array}{l}\text { Towarzystwo Chrystusowe dla Wychodźców. } \\
\text { Seminarium zagraniczne. Budowa gmachu }\end{array}$ & $1929-1934$ & 80 \\
\hline 90 & Miscellanea & 1922-1939 & 81 \\
\hline 91 & Paszporty i wizy & 1933-1934 & 82 \\
\hline 92 & Paszporty i wizy & 1934-1936 & 83 \\
\hline 93 & Paszporty i wizy & 1938-1939 & 84 \\
\hline 94 & Zatarg ks. Stefania c/a ks. Pawlak & 1927 & 85 \\
\hline 95 & Personalia ks. Józefa Styp Rekowskiego & 1929-1936 & 86 \\
\hline 96 & Personalia ks. Stefana Wullerta & 1931-1935 & 87 \\
\hline 97 & Personalia ks. Czesława Krzyszkowskiego & 1929-1939 & 88 \\
\hline 98 & Personalia ks. Stanisława Kopecia & 1929-1939 & 89 \\
\hline 99 & Personalia ks. Kazimierza Robera & 1934-1939 & 90 \\
\hline 100 & Niemcy. Personalia księży objazdowych & $1921-1938$ & 91 \\
\hline 101 & Niemcy - Westfalia - Nadrenia. Varia & 1916-1927 & $92 \mathrm{a}$ \\
\hline 102 & Niemcy - Westfalia - Nadrenia. Varia & $1928-1938$ & $92 \mathrm{~b}$ \\
\hline 103 & $\begin{array}{l}\text { Niemcy - Westfalia - Nadrenia. Związek Wzajemnej } \\
\text { Pomocy Tow[arzystw] P[olsko] K[atolickich] }\end{array}$ & 1924-1939 & 93 \\
\hline 104 & Niemcy. Szkolnictwo polskie & 1929-1939 & 94 \\
\hline 105 & Ziemia Święta. Dom Polski w Jerozolimie. Generalia & $1925-1935$ & $95 \mathrm{a}$ \\
\hline 106 & Ziemia Święta. Dom Polski w Jerozolimie. Generalia & 1934-1939 & $95 \mathrm{~b}$ \\
\hline 107 & Niemcy. Opieka Polska w Berlinie & $1927-1929$ & 96 \\
\hline 108 & Niemcy. Berlin & $1921-1937$ & 97 \\
\hline
\end{tabular}




\begin{tabular}{|c|l|c|c|}
\hline $\begin{array}{c}\text { Obecna } \\
\text { sygn. }\end{array}$ & \multicolumn{1}{|c|}{ Tytul jednostki } & Lata skrajne & Stara sygn. \\
\hline 109 & $\begin{array}{l}\text { Ziemia Święta. Dom Polski w Jerozolimie. Budżet. } \\
\text { Fundusze }\end{array}$ & $1927-1938$ & 98 \\
\hline 110 & Niemcy - Saksonia - Turyngia & 1921 & 99 \\
\hline 111 & Rosja Sowiecka. Księża & $1923-1939$ & 100 \\
\hline 112 & Sachalin & $1929-1937$ & 102 \\
\hline 113 & Jugosławia & $1925-1939$ & 103 \\
\hline 114 & Rumunia & $1927-1939$ & 104 \\
\hline 115 & Portugalia & $1935-1936$ & 105 \\
\hline 116 & Peru & $1928-1934$ & 106 \\
\hline 117 & Lotwa & $1923-1939$ & 107 \\
\hline 118 & Norwegia & $1927-1932$ & 108 \\
\hline 119 & Szwecja & $1925-1938$ & 109 \\
\hline 120 & Szwajcaria & $1928-1939$ & 110 \\
\hline
\end{tabular}

Dzial IV: Kancelaria wojenna (APP IV)

\begin{tabular}{|c|c|c|c|}
\hline $\begin{array}{l}\text { Obecna } \\
\text { sygn. }\end{array}$ & Tytul jednostki & Lata skrajne & Stara sygn. \\
\hline 1 & Wyjazd z Poznania - podróż do Rzymu - wizy, etc. & $1939-1940$ & OK 1 \\
\hline 2 & Broszury, okólniki, druki & 1939-1940 & OK 2 \\
\hline 3 & Węgry & $1939-1940$ & OK 3 \\
\hline 4 & Misja Polska w Londynie & 1939-1940 & OK 4 \\
\hline 5 & Misja Polska w Paryżu & $1939-1940$ & OK 5 \\
\hline 6 & Polacy we Francji & 1939-1940 & OK 6 \\
\hline 7 & Polacy we Włoszech & $1939-1940$ & OK 7 \\
\hline 8 & $\begin{array}{l}\text { Ambasciata di Polonia presso il Quirinale } \\
\text { - Ufficio Stampa }\end{array}$ & $1939-1940$ & OK 9 \\
\hline 9 & Anglia & $1939-1940$ & OK 10 \\
\hline 10 & Belgia i Holandia & $1939-1940$ & OK 11 \\
\hline 11 & Rumunia & $1939-1940$ & OK 12 \\
\hline 12 & Ameryka Południowa & $1939-1940$ & OK 14 \\
\hline 13 & $\begin{array}{l}\text { Situazione religiosa delle Archidiocesi di Gniezno } \\
\text { e di Poznań, } 1939\end{array}$ & 1939 & OK 15 \\
\hline 14 & $\begin{array}{l}\text { Situazione religiosa delle Archidiocesi di Gniezno } \\
\text { e di Poznań }\end{array}$ & 1940 & OK $15 b$ \\
\hline 15 & Stany Zjednoczone i Kanada & $1939-1940$ & OK $16 \mathrm{a}$ \\
\hline 16 & Stany Zjednoczone i Kanada & $1939-1940$ & OK 16b \\
\hline 17 & $\begin{array}{l}\text { Ks. Forecki - Paryż (Korespondencja ks. Foreckiego } \\
\text { z sekretarzem ks. Prymasa Hlonda w Rzymie) }\end{array}$ & 1940 & OK 17 \\
\hline 18 & Odezwy - Przemówienia & $1939-1940$ & OK 18 \\
\hline 19 & Poznań & $1939-1940$ & OK 20 \\
\hline 20 & $\begin{array}{l}\text { Korespondencja dotycząca święceń oraz przyjęcia do } \\
\text { seminarium }\end{array}$ & 1943-1944 & OK 21 \\
\hline 21 & Korespondencja rodzinna Jego Eminencji & $1939-1940$ & OK 22 \\
\hline
\end{tabular}




\begin{tabular}{|c|l|c|c|}
\hline $\begin{array}{c}\text { Obecna } \\
\text { sygn. }\end{array}$ & \multicolumn{1}{|c|}{ Tytul jednostki } & Lata skrajne & Stara sygn. \\
\hline 22 & Funkcje i przyjęcia w Rzymie & $1939-1940$ & OK 23 \\
\hline 23 & Gniezno & 1940 & OK 24 \\
\hline 24 & $\begin{array}{l}\text { Instytut - Kolegium - Hospicjum i kościół św. } \\
\text { Stanisława w Rzymie }\end{array}$ & $1939-1940$ & OK 25 \\
\hline 25 & Komitet Pomocy Moralnej przy Prymasie Polski & $1939-1940$ & OK 26 \\
\hline 26 & $\begin{array}{l}\text { Różne kraje Europy (Jugosławia, Szwajcaria, } \\
\text { Norwegia, Szwecja) }\end{array}$ & $1939-1940$ & OK 29 \\
\hline 27 & Turyn (salezjanie) & $1939-1940$ & OK 30 \\
\hline 28 & Jeńcy wojenni & $1939-1940$ & OK 31 \\
\hline 29 & Rekomendacje & $1939-1940$ & OK 32 \\
\hline 30 & Zgromadzenie Chrystusowców (Potulice) & $1939-1940$ & OK 33 \\
\hline 31 & Kondolencje z powodu upadku Polski & 1939 & OK 34 \\
\hline 32 & Ofiary dla uchodźców (ubrania etc.) & $1939-1940$ & OK 35 \\
\hline 33 & Ofiary pieniężne (pokwitowania wydatków) & $1939-1940$ & OK 36 \\
\hline 34 & Celebrety - Litterae Dimissoriales et simil & $1939-1940$ & OK 37 \\
\hline 35 & Poszukiwania osób w Polsce & $1939-1940$ & OK 38 \\
\hline 36 & Sprawozdanie z sytuacji Kościoła w Polsce na dzień & 8 IV 1940 & OK 39 \\
\hline 37 & Kolonia Polska w Rzymie & $1939-1940$ & OK 8 \\
\hline 38 & Polska & $1939-1940$ & OK 13 \\
\hline 39 & Korespondencja z „,domami panującymi” & $1938-1939$ & OK 28 (51) \\
\hline 40 & Życzenia świąteczne i okolicznościowe & $1939-1940$ & OK 27 (55) \\
\hline & & & \\
\hline
\end{tabular}

\section{BIBLIOGRAFIA}

\section{Źródła rękopiśmienne}

Archiwum Archidiecezjalne w Gnieźnie (AAG)

Akta Kurii Metropolitalnej w Gnieźnie. Dział I

sygn. 1823, Archiwum Archidiecezjalne [1956-1968]

Archiwum Prymasa Polski. Dział I

sygn. 169, Pałac prymasowski w Warszawie [1921-1932]

Archiwum Sekretariatu Archiwum Archidiecezjalnego w Gnieźnie

b. sygn., Księga zajęć 2 IX 1973 - 17 IV 1977.

b. sygn., Notatki ks. Mariana Aleksandrowicza do katalogu Archiwum Prymasa Polski, zeszyt 1

\section{Źródla drukowane}

Co do właściwego adresowania, „Miesięcznik Kościelny Archidiecezji Gnieźnieńskiej i Poznańskiej”, 44 (1927) nr 2, s. 1.

Statut Archiwum Archidiecezjalnego w Gnieźnie, „Wiadomości Archidiecezji Gnieźnieńskiej”, 43(1988) nr 7-8-9, s. 183-185. 


\section{Opracowania}

Aleksandrowicz M., Rył J., Zientarski W., Archiwum Archidiecezjalne w Gnieźnie, w: Dzieje Poznania i województwa poznańskiego (w granicach z 1974 r.). Informator o materiałach archiwalnych, red. Cz. Skopowski, Warszawa 1982, s. 85-235.

Banaszak M., Lenort F., Archiwum Archidiecezjalne w Poznaniu, w: Dzieje Poznania $i$ województwa poznańskiego ( $w$ granicach z 1974 r.). Informator o materiałach archiwalnych, red. Cz. Skopowski, Warszawa 1982, s. 237-487.

Fąka M., Kwestia prymasostwa w okresie arcybiskupich rządów kardynała Edmunda Dalbora (1915-1926), „Prawo Kanoniczne”, 20 (1977) nr 3-4, s. 109-129.

Filipiak B., Niektóre wiadomości o Kardynale Prymasie Auguście Hlondzie z czasów wojny 1939-1945, , Sacrum Poloniae Millennium”, 11 (1965) s. 480-491.

Kosiński S., August Hlond 1926-1948, w: Na stolicy prymasowskiej w Gnieźnie i Poznaniu. Szkice o prymasach Polski w okresie niewoli narodowej i w II Rzeczypospolitej, red. F. Lenort, Poznań 1982, s. 319-370.

Krucki Ł., Jak powstała Kuria Arcybiskupia w Gnieźnie? O ustanowieniu centralnego urzędu archidiecezji gnieźnieńskiej $w$ dwudziestoleciu międzywojennym, w: Kurie (archi)diecezjalne Kościoła rzymskokatolickiego w II Rzeczypospolitej, red. M. Dębowska, Lublin 2016, s. 17-35.

Krucki Ł., Rubrycele i schematyzmy archidiecezji gnieźnieńskiej. Katalog druków przechowywanych w Archiwum Archidiecezjalnym w Gnieźnie, Gniezno 2016.

Rybus H., Regesty wybranych zapisek z akt działalności arcybiskupów gnieźnieńskich, „Archiwa, Biblioteki i Muzea Kościelne”, 3 (1961) s. 111-404.

Wilczyński L., Ordynariat Arcybiskupi w Poznaniu i Kancelaria Prymasa Polski w dwudziestoleciu międzywojennym, „Ecclesia. Studia z dziejów Wielkopolski”, 1 (2003) s. 261-273.

Wilk S., Archidiecezja gnieźnieńska pod rzadami arcybiskupów: Edmunda Dalbora (1915-1926) i Augusta Hlonda (1926-1948), w: 1000 lat Archidiecezji Gnieźnieńskiej, red. J. Strzelczyk, J. Górny, Gniezno 2000, s. 379-394.

Wilk S., Archidiecezja gnieźnieńska w II Rzeczypospolitej. Administracja archidiecezji pod rzadami kard. Edmunda Dalbora i kard. Augusta Hlonda, Lublin 1987.

Wilk S., Funkcja Prymasa Polski w II Rzeczypospolitej, „Studia Theologica Varsaviensia", 26 (1988) nr 2, s. 161-188.

Wilk S., Kancelaria konsystorska w zaborze pruskim na przełomie XIX i XX w., „Archiwa, Biblioteki i Muzea Kościelne”, 64 (1995) s. 41-47.

\section{Netografia}

http://www.archiwum.archidiecezja.pl/news/97/56/Zakonczono-oprawianie-teczek-z-Archiwum-Prymasa-Polski.html (dostęp: 24.06.2017). 


\section{ZESPÓŁ ARCHIWUM PRYMASA POLSKI W ZASOBIE ARCHIWUM ARCHIDIECEZJALNEGO W GNIEŹNIE}

\section{Streszczenie}

Archiwum Archidiecezjalne w Gnieźnie, które zostało powołane do istnienia w 1960 r., skupia w swoim zasobie m.in. Archiwum Prymasa Polski z okresu międzywojennego, wojennego oraz powojennego (do 1948 r.). Archiwum Prymasa Polski w swojej strukturze dzieli się na trzy działy. Dział I (Prymas Polski) obejmuje sprawy związane z szeroko pojmowaną aktywnością kardynałów Edmunda Dalbora i Augusta Hlonda na polu kościelnym i państwowym i w swoim zasobie skupia 228 jednostek archiwalnych. Dział II (Ordynariusz gnieźnieński i poznański) skupia się na sprawach odnoszących się do działalności arcybiskupów Edmunda Dalbora i Augusta Hlonda jako ordynariuszy gnieźnieńskich i poznańskich i obejmuje 105 jednostek archiwalnych. Dział III (Protektor Spraw Wychodźstwa) podejmuje różnorodne kwestie związane z aktywnością prymasów okresu międzywojennego wśród Polonii oraz wśród polskich emigrantów i robotników sezonowych, licząc 120 jednostek archiwalnych. Dodatkowo został wyodrębniony dział IV - „okres wojenny”, który liczy 40 jednostek archiwalnych. Archiwum Prymasa Polski stanowi zatem cenne źródło do poznania historii Kościoła, Polski i Polonii w latach 19191948.

Słowa kluczowe: prymasostwo; archidiecezja gnieźnieńska; archidiecezja poznańska; Polonia; Kościół w Polsce; dwudziestolecie międzywojenne; relacje Kościół-państwo; kancelaria prymasowska

\section{THE FONDS THE PRIMATE OF POLAND ARCHIVE IN THE ARCHDIOCESAN ARCHIVE IN GNIEZNO}

\section{Summary}

The Archdiocesan Archive in Gniezno, which was created in 1960, includes, among others, the Primate of Poland Archive from the period of the interwar, war and post-war (until 1948). The Primate of Poland Archive is divided into three sections. Section I (The Primate of Poland) encompasses the issues connected with the broadly understood church and state activity of two primates, Edmund Dalbor and August Hlond and it includes 228 archival units. Section II (the Gniezno and Poznań Ordinaries) focuses on the issues connected to the activity of Archbishops Edmund Dalbor and August Hlond as the Gniezno and Poznań ordinaries and includes 105 archival units. Section III (The Protector of Emigration Affairs) refers to various issues connected with the primates' activity among the Polish community abroad (also among seasonal workers) during the interwar period; it has 120 archival units. In addition, Section IV (The war period) was created, which includes 40 archival units. The Primate of Poland Archive is a valuable source for the history of the Church, Poland and the Polish community abroad in the years 1919-1948.

Keywords: primacy; the archdiocese of Gniezno; the archdiocese of Poznań; Polish community abroad; the Church in Poland; interwar period; the Church-state relationships; Primate's office 